\title{
Climate change over the high-mountain versus plain areas: Effects on the land surface hydrologic budget in the Alpine area and northern Italy
}

\author{
Claudio Cassardo ${ }^{1,2,4}$, Seon Ki Park ${ }^{2,3,4}$, Marco Galli ${ }^{1, a}$, and Sungmin $\mathbf{O}^{5, \mathrm{~b}}$ \\ ${ }^{1}$ Department of Physics and NatRisk Center, University of Torino "Alma Universitas Taurinorum”, Torino, Italy \\ ${ }^{2}$ Department of Climate and Energy Systems Engineering, Ewha Womans University, Seoul, Republic of Korea \\ ${ }^{3}$ Department of Environmental Science and Engineering, Ewha Womans University, Seoul, Republic of Korea \\ ${ }^{4}$ Center for Climate/Environment Change Prediction Research and Severe Storm Research Center, \\ Ewha Womans University, Seoul, Republic of Korea \\ ${ }^{5}$ Institute for Geophysics, Astrophysics, and Meteorology, University of Graz, Graz, Austria \\ ${ }^{a}$ now at: Air Force Mountain Centre, Sestola, Modena Province, Italy \\ ${ }^{b}$ now at: Department of Biogechemical Integration, Max Planck Institute for Biogeochemistry, Jena, Germany
}

Correspondence: Seon Ki Park (spark@ewha.ac.kr)

Received: 18 September 2017 - Discussion started: 18 October 2017

Revised: 17 February 2018 - Accepted: 13 May 2018 - Published: 14 June 2018

\begin{abstract}
Climate change may intensify during the second half of the current century. Changes in temperature and precipitation can exert a significant impact on the regional hydrologic cycle. Because the land surface serves as the hub of interactions among the variables constituting the energy and water cycles, evaluating the land surface processes is essential to detail the future climate. In this study, we employ a trusted soil-vegetation-atmosphere transfer scheme, called the University of Torino model of land Processes Interaction with Atmosphere (UTOPIA), in offline simulations to quantify the changes in hydrologic components in the Alpine area and northern Italy, between the period of 1961-1990 and 2071-2100. The regional climate projections are obtained by the Regional Climate Model version 3 (RegCM3) via two emission scenarios - A2 and B2 from the Intergovernmental Panel on Climate Change Special Report on Emissions Scenarios. The hydroclimate projections, especially from A2, indicate that evapotranspiration generally increases, especially over the plain areas, and consequently the surface soil moisture decreases during summer, falling below the wilting point threshold for an extra month. In the high-mountain areas, due to the earlier snowmelt, the land surface becomes snowless for an additional month. The annual mean number of dry (wet) days increases remarkably (slightly), thus increasing the risk of severe droughts, and slightly increasing the risk of
\end{abstract}

floods coincidently. Our results have serious implications for human life, including agricultural production, water sustainability, and general infrastructures, over the Alpine and adjacent plain areas and can be used to plan the managements of water resources, floods, irrigation, forestry, hydropower, and many other relevant activities.

\section{Introduction}

Recent reports from the Intergovernment Panel on Climate Change (IPCC), based on the coupled atmosphere-ocean general circulation models (GCMs), on the condition of increasing concentration of greenhouse gases (IPCC, 2007, 2013) indicate that climate change by the end of this century (e.g., increase in the mean temperature and change in the precipitation amount) is expected to occur irregularly in space and time but to mostly affect some specific and critical regions (Beniston, 2006), including the vicinity of the Mediterranean - well known as one of the world's climatic hotspots (Giorgi, 2006; Diffenbaugh and Giorgi, 2012; Gobiet et al., 2014; Vautard et al., 2014; Coppola et al., 2016; Paeth et al., 2017). Within this region, the Alpine and adjacent areas are expected to undergo a relatively larger temper- 
ature increase (Giorgi and Lionello, 2008), which has been generally confirmed since the IPCC Fourth Assessment Report (AR4; IPCC, 2007).

In a generic mesoscale basin, such potential changes will influence hydrologic budget, thus altering the amount of available water and acting as climate feedback. Previous studies conducted over the alpine areas (Giorgi et al., 1997; Beniston et al., 2007; Kotlarski et al., 2015) demonstrated amplification of the climate change signal by topography through local hydroclimatic and land surface feedbacks: the snow cycle plays a key role as variations in the cycle of snowpack accumulation and melting affect the generation of snowmelt-driven runoff. In addition, the temperature and seasonal precipitation pattern changes can affect the permanent or seasonal snowmelt, thus affecting streamflow timings, groundwater recharge, and runoff, and consequently the water availability. Even where the precipitation will increase, the concurrent warming will favor a further increase in evapotranspiration. The decrease in water supplies, conjunctly with the likely increase in the demand, could significantly influence agriculture (the largest consumer of water) as well as municipal, industrial, and other uses (EEA, 2005). Nevertheless, to evaluate the local net effect of changing climate on water resources, the hydrologic budget must be detailed (Bocchiola et al., 2013).

Seasonal variations of temperature and precipitation also drive changes in runoff and streamflow: for instance, the spring peak streamflow may occur earlier than the present in places where snowpack significantly determines the water availability (IPCC, 2007). Such changes may seriously influence the water and flood management, often with significant economic consequences, though the resulting effects may differ for regions even at similar latitudes, as evidenced by Adam et al. (2009) for the high latitudes of North America and Eurasia.

Usually GCMs are calculated in relatively coarse grid spacings, thus inadequately representing the regional topography and climate (Bhaskaran et al., 2012). Therefore, downscaling of the GCM variables to regional scale is essential for a better depiction of regional climate: the dynamic downscaling uses the regional climate models (RCMs) with a higher resolution (typically $10-50 \mathrm{~km}$ ) and the same principles of dynamical and physical processes as GCMs (e.g., Wilby and Wigley, 1997; Christensen et al., 2007; Jury et al., 2015). It is demonstrated that RCMs significantly improve the model precipitation formulation (e.g., Frei et al., 2006; Gao et al., 2006; Buonomo et al., 2007; Boberg et al., 2009). In this context, a project called the Prediction of Regional scenarios and Uncertainties for Defining EuropeaN Climate change risks and Effects (PRUDENCE; http://prudence.dmi.dk/, last access: 15 September 2017) was undertaken, aiming at providing high-resolution climate change scenarios for Europe at the end of the 21 st century via dynamical downscaling of global climate simulations (Christensen et al., 2007). Déqué et al. (2005) found that, over Europe, GCMs and RCMs be- have similarly for the seasonal mean temperature with higher spread in GCMs; however, during summer, the spread of the RCMs - particularly in terms of precipitation - is larger than that of the GCMs, which indicates that the European summer climate is strongly controlled by parameterized physics and/or high-resolution processes. They also concluded that the PRUDENCE results were confident because the models had a similar response to the given radiative forcing. Déqué et al. (2007) showed that the signal from the PRUDENCE ensemble is significant in terms of the minimum expected $2 \mathrm{~m}$ temperature and precipitation responses. Jacob et al. (2007a) demonstrated that RCMs in PRUDENCE generally reproduce the large-scale circulation of the driving GCM. Coppola and Giorgi (2010) found a broad agreement, in the 21st century climate projections over Italy, between the results obtained from the ensembles of PRUDENCE and the Coupled Model Intercomparison Project (CMIP; https://cmip.llnl.gov/, last access: 15 February 2018) Phase 3 (CMIP3); however, the CMIP3 GCMs showed a much larger range of bias for temperature and precipitation than the PRUDENCE RCMs. These studies indicate that results from the PRUDENCE and CMIP3/CMIP Phase 5 (CMIP5) experiments are roughly equivalent for the Mediterranean region and the Alpine sector.

The GCMs represent the large-scale atmospheric and oceanic processes. Even if they include sophisticated atmospheric physics and feedbacks with land surface and ocean conditions, they only show conditions averaged over large areas. Hydrologic processes normally operate at relatively smaller scales, i.e., mesoscale and storm scale in meteorology and basin scale in hydrology, and local conditions can be most extreme than those suggested by the areal mean values (see, e.g., the analysis on the groundwater use and recharge in Crosbie et al., 2005). Several recent studies attempted to evaluate the hydrologic effects of climate changes in individual small-scale catchments using a variety of water balance models and climate change scenarios (e.g., Nemec and Schaake, 1982; Gleick, 1986, 1987; Flaschka et al., 1987; Bultot et al., 1988; Ayers et al., 1990; Lettenmaier and Gan, 1990; Klausmeyer, 2005; Buytaert et al., 2009; Berg et al., 2013). Despite of some differences in results, due to the different forcing data or scenarios used (Rind et al., 1992), they have gathered some suitable information at basin or regional scale.

These studies also reveal that the land surface has been recognized as a critical component for the climate. Key points are the partitioning of solar radiation into sensible and latent heat fluxes, and that of precipitation into evaporation, soil storage, groundwater recharge, and runoff. Despite the increased consideration of such processes, the land surface parameters are not systematically measured at either large scale or mesoscale, making it hard to perform hydrologic analyses. To overcome such a problem, we have used a methodology called the CLImatology of Parameters at the Surface (CLIPS), proposed by some other studies (e.g., Cassardo et 
al., 1997, 2009). According to CLIPS, the output of a land surface model (LSM) is used as a surrogate of surface observations, to estimate the surface layer parameters.

The goal of this study is to investigate the effects of climate change, based on high and low emission scenarios, on the hydrologic components in the Alpine and adjacent areas, including the Po Valley in Italy, near the end of this century. Section 2 describes the details of RCM and LSM employed in this study, and Sect. 3 describes the experiment design. Results concerning the hydrologic budget are reported in Sect. 4, and conclusions are provided in Sect. 5.

\section{Description of the models}

In this study, calculation of the future hydrologic budget components has been performed through the University of Torino model of land Processes Interaction with Atmosphere (UTOPIA; Cassardo, 2015): meteorological inputs to drive UTOPIA under the current and future climate conditions are obtained from the Regional Climate Model version 3 (RegCM3). Since the details of the RegCM3 run have already been published (Giorgi et al., 2004a, b; Gao et al., 2006), here a short description of RegCM3 will be given. Regarding UTOPIA, just some portions relevant for this study are described.

Despite the availability of the products for Europe within the World Climate Research Program COordinated Regional Downscaling EXperiment (EURO-CORDEX; http: //www.euro-cordex.net/, last access: 5 February 2018), which includes a newer version of RegCM (i.e., RegCM4), we decided to employ RegCM3 for the following reasons: (1) RegCM3 had been employed in several important projects, including PRUDENCE, ENSEMBLES (http:// ensembles-eu.metoffice.com/, last access: 5 February 2018), and the Central and Eastern europe Climate change Impact and vulnerabiLIty Assessment (CECILIA; http://www. cecilia-eu.org/, last access: 5 February 2018), whose outputs had been used in numerous studies focusing on Europe (e.g., Blenkinsop and Fowler, 2007; Christensen and Christensen, 2007; Ballester et al., 2010; Coppola and Giorgi, 2010; Herrera et al., 2010; Rauscher et al., 2010; Kyselý et al., 2011; Torma et al., 2011; Heinrich et al., 2014; Skalák et al., 2014; Faggian, 2015); (2) RegCM3 had also been widely used, even most recently, for the studies of climate projections, model evaluations, and sensitivities over the target areas in our study - the Alpine and adjacent areas (e.g., Gao et al., 2006; Smiatek et al., 2009; Coppola and Giorgi, 2010; Im et al., 2010; Coppola et al., 2014; Nadeem and Formayer, 2016; Alo and Anagnostou, 2017); (3) since plenty of model outputs were available from several relevant projects (e.g., PRUDENCE, ENSEMBLES, CECILIA, etc.) and we had limited resources for exploring all available data sources, we decided to select a well-known model which had been extensively used for such kind of studies.

\section{$2.1 \quad \operatorname{RegCM3}$}

The earliest version of RegCM was originally proposed by Dickinson et al. (1989) and Giorgi (1990) to use limitedarea models as a tool for regional climate studies, with the aim of downscaling the GCM results. In this way, the GCM runs could provide the initial conditions and time-dependent boundary conditions to RCMs.

The dynamical core of RegCM3 is based on the hydrostatic version of the National Center for Atmospheric Research/Pennsylvania State University Mesoscale Model version 5 (MM5: Grell et al., 1994). The RegCM is a hydrostatic and compressible primitive equation model with a $\sigma$ vertical coordinate. More details on RegCM3 are referred to in the MM5 documentation (Grell et al., 1994) and some papers describing previous versions of RegCM (e.g., Giorgi et al., 1993; Giorgi and Shields, 1999). The RegCM3 is documented in Elguindi et al. (2007).

The RegCM3 includes several physical process packages. Precipitation involves both grid- and subgrid-scale processes (e.g., Pal et al., 2000), which are crucial as a source of errors in climate simulations (e.g., Nakicenovic and Swart, 2001). The implemented subgrid precipitation schemes are described in Anthes (1977), Emanuel (1991), Giorgi (1991), Grell (1993), and Emanuel and Živković-Rothman (1999). The physics of the surface processes is described according to the Biosphere-Atmosphere Transfer Scheme (BATS) manual (Dickinson et al., 1993). Subgrid differences in topography and land use are taken into account using a mosaictype approach (Giorgi et al., 2003b). Two kinds of water bodies are considered - open (e.g., oceans) and closed (e.g., lakes).

The open-water bodies are described by the water temperature, introduced as a boundary condition for the model. The closed ones are treated as the open bodies, or using a specific one-dimensional lake model interacting in two ways with the atmosphere (Hostetler and Bartlein, 1990). Aerosols and chemical compounds are considered, accounting for their diffusion and removal processes, as well as the radiative effects; details about the RegCM3 chemistry are found in Qian et al. (2001), Giorgi et al. (2003a), and Solomon et al. (2006).

The RegCM3 has been employed and tested in various contexts, on various space scales, for a broad range of scientific problems, including climate change (Giorgi et al., 2004a, b; Diffenbaugh et al., 2005; Gao et al., 2006), air quality (Solomon et al., 2006), water resources (Pal and Eltahir, 2002), extreme events (Pal et al., 2004), agriculture (White et al., 2006), land cover change (Abiodun et al., 2007), and biosphere-atmosphere interactions (Pal and Eltahir, 2003). 


\subsection{UTOPIA}

The UTOPIA is a diagnostic one-dimensional model, formerly named the Land Surface Process Model (LSPM; Cassardo et al., 1995; Cassardo, 2006). It can be used on a standalone basis or be coupled with an atmospheric circulation model or an RCM, serving as the lower boundary condition. All specific details about its use and features are fully described in Cassardo (2015).

The land surface processes in UTOPIA are described in terms of physical fluxes and hydrologic states of the land. The former includes radiation fluxes, momentum fluxes, sensible and latent energy fluxes, and heat transfer in multi-layer soil, while the latter includes snow accumulation and melt, rainfall, interception, infiltration, runoff, and soil hydrology. All the fluxes are computed using an electric analogue formulation, in which the fluxes are directly proportional to the gradients of the related scalars and inversely proportional to the adequate resistance.

The UTOPIA domain is vertically subdivided into three main zones - the soil, the vegetation, and the atmospheric layer within and above the vegetation canopy layer. Variables are mainly diagnosed in the soil and in the vegetation layers. The canopy itself is represented as a single uniform layer (i.e., big leaf approximation), whose properties are described by vegetation cover and height, leaf area index, albedo, minimum stomatal resistance, leaf dimension, emissivity, and root depth. The soil state is described by its temperature and moisture content. These variables are calculated by the integration of the heat Fourier equation and conservation of water mass equation using a multi-layer scheme. The main parameters include thermal and hydraulic conductivities, soil porosity, permanent wilting point, dry heat capacity, surface albedo, and emissivity. The UTOPIA can have as many soil layers as a user specifies; however, a sufficient number of layers is required for numerical stability. Note that numerical stability is strictly related to the integration time step the model becomes unstable and blows up eventually with an inadequately large time step. This is particularly true in the presence of strong moisture gradients, which could lead to errors in the representation of soil moisture profiles.

Finally, the presence of snow is parameterized with a single layer assumption. Snow can cover vegetation and bare soil separately and possesses its proper energy and hydrologic budgets, thus interacting with the other components.

The UTOPIA is a diagnostic model; thus, some observations in the atmospheric layer are required as boundary conditions, including air temperature, humidity, pressure, wind speed, cloud cover, longwave and shortwave incoming radiation, and precipitation rate. Usually these observations are measured values, along with the reconstruction of some missing data using adequate interpolation techniques.

The UTOPIA, as well as its predecessor LSPM since 2008, has been tested with field campaigns and measured data either by itself or as coupled with an atmospheric circulation model. Examples of its use can be found in several studies. Ruti et al. (1997) compared LSPM and BATS in the Po Valley, Italy. Cassardo et al. (1998) studied its dependence on initialization. Cassardo et al. (2005) used LSPM to study surface energy and hydrologic budget on the synoptic scale. Cassardo et al. $(2002,2006)$ used the LSPM to analyze extreme flood events in Piedmont, Italy. In Cassardo et al. (2007), LSPM has been used to study the 2003 heat wave in Piedmont. Studies with LSPM on non-European climates have also been accomplished, related to very dry sites (Feng et al., 1997; Loglisci et al., 2001), to the onset of the Asian monsoon (Cassardo et al., 2009), and to the soil temperature response in Korea to a changing climate (Park et al., 2017). The UTOPIA was also coupled with the Weather Research and Forecast (WRF) model, version 3, and applied to a flash flood caused by a landfall typhoon, as well as to the exceptionally wet period 2008-2009 in the northwestern Italy (Zhang et al., 2009, 2011). Recent applications include studies on the parameterization of soil freezing (Bonanno et al., 2010), and the cold spells over the Alpine area and the Po Valley (Galli et al., 2010). It has also been applied to studies on vineyards environment, including canopy resistance (Prino et al., 2009), energy and hydrologic budgets (Francone et al., 2010), sensitivity to vegetation parameters (Francone et al., 2012a), and an analysis of turbulence (Francone et al., 2012b).

\section{Experimental design}

The goal of this study is to evaluate the components of the surface hydrologic budget on a mesoscale area from a climatic point of view, and to compare the effects of the climate change on these values. Two 30-year periods have been considered: the first one (1961-1990) is the baseline period or reference climate ( $\mathrm{RC})$, whereas the other is the last 30 years of the 21st century (2071-2100), named the future climate (FC) here. The period 1961-1990 has been employed in numerous previous studies on climate change projections and impacts, even very recently (e.g., Giorgi and Lionello, 2008; Smiatek et al., 2009; Ciscar et al., 2011; Kyselý et al., 2011; Torma et al., 2011; Heinrich et al., 2014; Perez et al., 2014; Skalák et al., 2014; Belda et al., 2015; Dunford et al., 2015; Faggian, 2015; Casajus et al., 2016; Harrison et al., 2016; Gang et al., 2017; Paeth et al., 2017). It had also been used in various climate projection projects using GCMs and/or RCMs, such as CMIP3/CMIP5, PRUDENCE, ENSEMBLES, and CECILIA.

The climate projections are obtained through the IPCC Special Report on Emissions Scenarios (SRES) A2 and B2 emission scenarios (Nakicenovic and Swart, 2001). Note that the A2 scenario assumes large increases in population and economical development while the B2 scenario assumes more sustainability and consequent smaller increases in those; thus, the concentration of carbon dioxide are pro- 
jected to be higher for A2 than for B2. The future climates based on the $\mathrm{A} 2$ and $\mathrm{B} 2$ scenarios are hereafter referred to as $\mathrm{FC}_{\mathrm{A} 2}$ and $\mathrm{FC}_{\mathrm{B} 2}$, respectively.

In the last decade, numerous studies on climate projections and impacts have been conducted using the SRES scenarios, which were the base scenarios in the CMIP3 experiments. After the emergence of new scenarios - Representative Concentration Pathways (RCPs; Moss et al., 2010), which were employed in the IPCC Fifth Assessment Report (AR5; IPCC, 2013) and the CMIP5 experiments, there have been many studies either to check similarities and/or differences between the two scenario sets for a given projection period (e.g., Riahi et al., 2011; Ward et al., 2011; Rogelj et al., 2012; Matthews and Solomon, 2013; Baker and Huang, 2014) or to address the value of using both scenario sets for future climate projections (e.g., Peters et al., 2013; O'Sullivan et al., 2016; Nolan et al., 2017).

It turns out that both SRES and RCP scenarios are generally in good agreements, for pairs of closest counterparts, in projecting climate in the 21 st century. For example, Riahi et al. (2011) mentioned that SRES A2 was comparable to RCP 8.5. Ward et al. (2011) found that the RCP 4.5 and SRES B1/A1T scenarios were broadly consistent with the fossil fuel production forecasts. Rogelj et al. (2012) pointed out that the RCP scenarios spanned a larger range of temperature estimates than the SRES scenarios, and indicated similar temperature projections for pairs between the two scenario sets: RCP 8.5 similar to A1FI, RCP6 to B2, and RCP 4.5 to B1, respectively. Matthews and Solomon (2013) showed that the cumulative $\mathrm{CO}_{2}$ emission and corresponding warming in the short term (2030) are approximately the same across all emission scenarios, whereas those in the longer term (2100) are similar between close counterparts of the selected SRES and RCP scenarios: A1FI to RCP 8.5, A1B to RCP 6, and B1 to RCP 4.5, respectively. Baker and Huang (2014) reported a common drying trend, over the Mediterranean region, between the CMIP3 simulations based on SRES A1B and the CMIP5 simulations based on RCPs 4.5 and 8.5. It is also indicated by Cabré et al. (2016) that SRES A2 has similarities to RCP 8.5 in terms of radiative forcing, future trajectories, and changes in global mean temperature. In Rogelj et al. (2012), differences in warming rates existed between the two scenario sets due to different transient forcings; however, with a 30-year average for each scenario as in our study, the results and conclusions of using the SRES A2/B2 scenarios would not be significantly different from those of using the closest RCP counterparts.

To obtain a broad range of projections, Peters et al. (2013) projected global warming through all available emission scenarios, showing that RCP 8.5 and SRES A1FI and A2 lead to the highest temperature projections. Most recently, O'Sullivan et al. (2016) and Nolan et al. (2017) assessed impacts of climate change on temperature and rainfall, respectively, by the mid-21st century in Ireland using both the SRES and RCP scenarios, and provided a wide range of possible climate projections. O'Sullivan et al. (2016) found that future summers had the largest projected warming under RCP 8.5 while future winters had the greatest warming under A1B and A2. Nolan et al. (2017) created a mediumto-low emission ensemble using the RCP4.5 and B1 scenario simulations and a high emission ensemble using the RCP8.5, $\mathrm{A} 1 \mathrm{~B}$, and $\mathrm{A} 2$ simulations, which enabled 25 high and 21 medium-to-low emission ensemble comparisons: they found significant projected decreases in mean annual, spring, and summer precipitation amounts - largest for summer, with different reduction ranges for different scenario ensembles.

Furthermore, the SRES scenarios by themselves have often been adopted in most recent studies, even long after the release of the RCP scenarios, because the old scenarios were in accord with their objectives (e.g., Dunford et al., 2015; Jaczewski et al., 2015; Kiguchi et al., 2015; Kim et al., 2015; Casajus et al., 2016; Harrison et al., 2016; Mamoon et al., 2016; Stevanović et al., 2016; Tukimat and Alias, 2016; Zheng et al., 2016; Hassan et al., 2017; Park et al., 2017; da Silva et al., 2017). We employed the SRES marker scenarios because of their long-term consistency in assessing the impact of climate change on global and regional factors of socioeconomy and environment during the last decade - including air quality (Jacob and Winner, 2009; Carvalho et al., 2010), water quality and resources (Wilby et al., 2006; Shen et al., 2008, 2014; Luo et al., 2013), energy (Hoogwijk et al., 2005; van Vliet et al., 2012), agriculture and forestry (Lavalle et al., 2009; Calzadilla et al., 2013; Stevanović et al., 2016; Zubizarreta-Gerendiain et al., 2016), fisheries (Barange et al., 2014; Lam et al., 2016), health and disease (Patz et al., 2005; Giorgi and Diffenbaugh, 2008; Ogden et al., 2014), climate and weather extremes (Déqué, 2007; Marengo et al., 2009; Jiang et al., 2012; Rummukainen, 2012), wildfires (Liu et al., 2010; Westerling et al., 2011), ecosystems and biodiversity (Araújo et al., 2008; Feehan et al., 2009; Jones et al., 2009; Fronzek et al., 2012; Walz et al., 2014), and so forth. Although an ensemble approach with all possible scenarios would increase the spread of hydrologic budget simulations, due to the limited resources, we decided to select two representative marker scenarios: A2 as the higher-end and B2 as the lower-end emission scenario, respectively.

Simulations of RegCM3 for the two periods (i.e., 19611990 and 2071-2100) are fully referenced in Giorgi et al. (2004a, b) and Gao et al. (2006), and have been chosen for this study because they are still among the highest-resolution datasets currently available. As shown in Coppola et al. (2016), the RCM outputs with high resolution can allow the hydrologic cycle to be efficiently reconstructed at a largebasin scale, even in an orographically complex area such as the Alps.

The domain for this study involves most of the Alpine region and the Po River basin, as shown in Fig. 1. It is bordered by the meridians 5 and $15^{\circ} \mathrm{E}$ and the parallels 43 and $48^{\circ} \mathrm{N}$. We have chosen this domain for two main reasons: (1) the Alps represent a critical environment that already answered 
most effectively to the recent climate warming (e.g., Beniston, 2006); and (2) the Alps are the source of the longest and greatest European rivers (e.g., Rhyne, Rhone, Danube, Inn, Arc, Po, etc.). Under these considerations, it is essential to evaluate potential changes in the soil variables and the hydrologic budgets, induced by climate change.

The RegCM3 outputs are provided on a Lambert grid, with a $20 \mathrm{~km}$ spatial resolution, containing 720 land grid points on the analyzed domain (Fig. 1). The domain is divided into three sets of grid points in terms of elevation: (1) one representing the plain or low-hill areas lower than or equal to $500 \mathrm{~m}$ above sea level (a.s.l.), occupying $34 \%$ (blue); (2) another depicting normal mountains between 500 and $2000 \mathrm{~m}$ a.s.l., occupying $57 \%$ (grey); and (3) the other belonging to the high-mountain areas higher than $2000 \mathrm{~m}$ a.s.l., occupying $9 \%$ (red). In this study, among all the possible outputs available from UTOPIA, we give particular attention to the state of soil moisture and the components of hydrologic budget - precipitation, evapotranspiration, drainage, and runoff. Note that some of those values were already included in the RegCM3 output database. However, the land surface model of RegCM3 employs an old force-restore method included in the BATS scheme which was demonstrated to be insufficient to properly evaluate hydrologic budget (Ruti et al., 1997). Therefore, we made an offline run with UTOPIA in order to allow a more realistic evaluation of the soil and budget components, and to have a self-consistent set of variables in equilibrium among themselves.

The UTOPIA has been driven using the following output of RegCM3 over each grid point of the domain - precipitation; short- and longwave radiation; and temperature, humidity, pressure and wind at surface (i.e., the lowest level of RegCM3). This procedure has been used for all three climates $\left(\mathrm{RC}, \mathrm{FC}_{\mathrm{A} 2}\right.$, and $\left.\mathrm{FC}_{\mathrm{B} 2}\right)$.

The UTOPIA has been configured to represent 10 soil layers, following Meng and Quiring (2008), who suggested the use of multiple soil layers to represent well the vertical heterogeneity in soil properties. The thickness of soil layers starts from $5 \mathrm{~cm}$ in the top layer, then doubles for every layer going to higher depths. The last layer must be interpreted as a boundary relaxation zone. The soil characteristics have been taken from the ECOCLIMAP database (Masson et al., 2003). No soil-freezing scheme is used, and initial values of soil moisture and temperature have been set following Cassardo (2015).

In terms of vegetation, short grasses are assumed to cover the whole domain. Actually the domain includes the Alps, the Apennines, off-alpine and hilly areas, and plains; thus, there is a wide range of vegetation. Regarding plains and hilly areas, vegetation includes pastures, grasslands, and some forested areas: mountain areas are mostly covered by trees, and the highest parts are without vegetation or covered by permanent ice (few grid points). We decided to set the vegetation type equal for all grid points (i.e., short grasses) for the following reasons: (1) for the "reference climate", to avoid any problem in interpretation of results due to the differences in vegetation, and (2) for the "future climate", to alleviate the uncertainty in vegetation type at the end of 21 st century. With regard to meteorological variables, this is not a bad assumption because most observation stations are normally installed over short grasses. Moreover, considering plant height, root depth, and vegetation characteristics, short grasses can be roughly regarded as most common cereals (wheat, maize, etc.), and would not be quite different from such kind of agricultural products. Finally, we have also performed simulations using the "true" vegetation (as deduced by detailed databases), and the results with the pastures and agricultural areas have generally been confirmed, though the numerical values of the variables were slightly different (not shown).

Although UTOPIA could be driven by the real observations in $\mathrm{RC}$, it is driven by the RegCM3 output in order to keep consistency among the RC and FC simulations and to exclude any possible source of errors caused by differences in input data, irregularity of grid, and/or interpolation of missing observations. In this way, we can compare the FC representations with an analogous RC representation. Thus, here the RegCM3 outputs for each grid point have been used as if they were observed data.

All RegCM3 outputs were available with a time resolution of $3 \mathrm{~h}$, and used as input data to UTOPIA. In order to ensure numerical stability of the UTOPIA simulations, these input data, except precipitation, have been interpolated at a rate of one datum per hour: we applied a cubic spline (Burden and Faires, 2004) to the non-intermittent variables like temperature, humidity, and radiation (flux). The intermittent variable like precipitation was simply redistributed to keep its sum, assuming a constant rate: the input data of precipitation were the precipitation cumulated over the timesteps of the RCM output, and could not be interpolated with splines. Although we could have converted precipitation to precipitation rates, interpolated them using splines, and then reconverted to cumulated precipitation over the smaller timestep of UTOPIA, the result of such a complicated procedure was almost equivalent to using the method employed here. Regarding radiation and wind components, we used the splines for the sake of uniformity with other variables. Then, we further controlled some unrealistic values (e.g., negative radiations): we controlled the daily means (or cumulated values) from input (from RegCM3) and output (for UTOPIA) of the interpolation to be non-negative values.

In this study, we employed a single-model approach that has relatively larger uncertainty: it is desirable to employ an ensemble approach, using multiple models and/or initial conditions, to estimate the range of climate projections. Our decision to employ the single-model approach is mainly due to limitations in resources to perform multi-model ensemble simulations for both the RCM and land surface model. Given such limitations, a high-resolution single model is often an alternative choice, especially over a complex ter- 
(a)



(b)

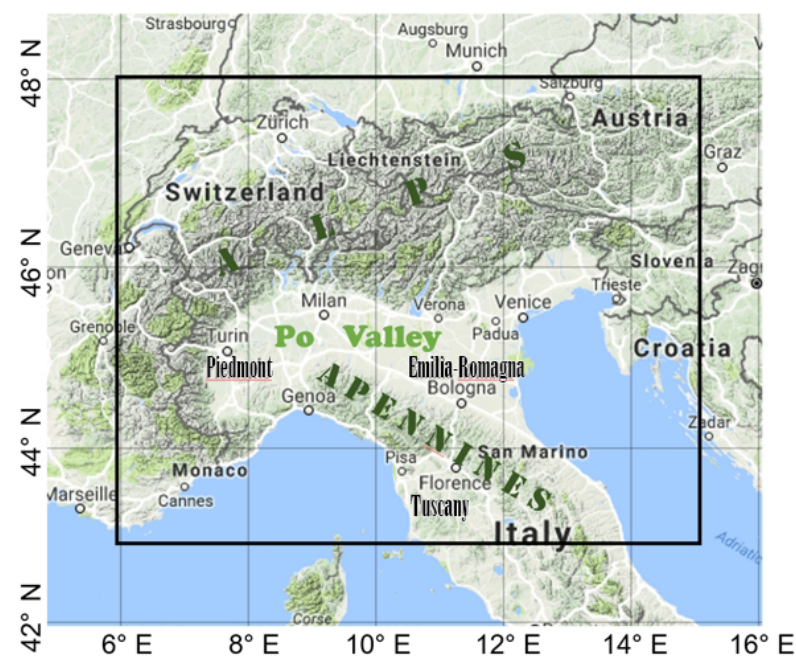

Figure 1. Computational domain with grid points (a) and geographic map (b) with boundary of the study area (black solid lines). Grid points represent, in terms of the grid elevation $(h)$, the plain area ( $h \leq 500 \mathrm{~m}$ a.s.l.; blue), the normal mountains $(500<h \leq 2000 \mathrm{~m}$ a.s.l.; grey), and the high-mountain area $(h>2000$ m a.s.l.; red). The map on the right panel is modified from Google Maps.

rain. Coppola and Giorgi (2010) made a fine-scale $(20 \mathrm{~km})$ single-model experiment using RegCM3 and found that both the temperature and precipitation changes via $\mathrm{RegCM} 3$ were in line with the CMIP3 and PRUDENCE ensemble results. Generally speaking, multi-model ensembles tend to decrease the errors compared to an individual model; however, due to the averaging operation (e.g., ensemble mean), the spatial and temporal variability of the signal tends to decrease. Moreover, many previous studies on various climate change impacts and projections had been performed using the singlemodel approach (e.g., Dankers and Feyen, 2008; Beniston, 2009; Im et al., 2010; Krüger et al., 2012; Zanis et al., 2012; Tainio et al., 2013; Park et al., 2017).

The multiple simulations performed for RC and FCs are presented in terms of the temporal and spatial variability by displaying time series (annual cycles) and two-dimensional maps, respectively, of the mean values of some variables. For time averaging, Xu and Singh (1998) suggested using monthly mean values for discussing the hydrologic budget variations induced by climate change; however, we preferred a period of 10 days to better quantify time shifts of the physical variables. In this study, the annual cycles are figured via the 10-day averages over the 30-year simulation period, at each elevation-categorized grid-point set. Each month has three 10-day periods: days 1 to 10,11 to 20 , and 21 to the end of the month.

The analyzed variables include precipitation (PR), evapotranspiration (ET), surface runoff (SR), and soil moisture (SM). We noticed that the general trends of annual cycles are similar between RC and FCs. Therefore, in order to accentuate the extent and direction of changes, the future variations in the hydrologic budget components are shown as the differ- ences between FCs and RC; the PR difference $(\triangle \mathrm{PR})$ represents $\mathrm{PR}_{\mathrm{FC}}$ minus $\mathrm{PR}_{\mathrm{RC}}$, where $\mathrm{FC}$ is either $\mathrm{FC}_{\mathrm{B} 2}$ or $\mathrm{FC}_{\mathrm{A} 2}-$ similarly to $\Delta \mathrm{ET}$ and $\Delta \mathrm{SR}$.

In this study, SM is defined as the quantity of water contained in soil that is composed of solid particles, air, and water, and it is represented as saturation ratio $(S)$ :

$S=\frac{V_{\mathrm{w}}}{V_{\mathrm{w}}+V_{\mathrm{a}}}=\frac{V_{\mathrm{w}}}{V_{\mathrm{v}}}$

where $V_{\mathrm{w}}, V_{\mathrm{a}}$, and $V_{\mathrm{v}}$ are the volumes of water, air, and voids, respectively, in soil.

\section{Results and discussion}

In this section, we provide analyses on temporal variability and spatial distribution of hydrologic budget components, making comparisons between RC and FCs. The potential change in dryness (wetness) is also assessed through the projection of the number of dry (wet) days. Finally, we compare our findings with relevant previous studies, and discuss consistency and uniqueness of our study.

\subsection{Temporal variability of evapotranspiration, precipitation, runoff and soil moisture}

Figure 2 compares the annual cycle of PR, ET, and SR in the plain area $(h \leq 500 \mathrm{~m}$ a.s.l.). In the RC summer, ET exceeds PR from the end of June (when ET peaks to about $22 \mathrm{~mm}$ ) to the end of August (when SM is minimal around $0.52 \mathrm{~m}^{3} \mathrm{~m}^{-3}$; see Fig. 3). PR shows its minimum between mid-June and August, when it is lower than ET. In the RC winter, PR is much higher than ET, and SR exceeds ET from 

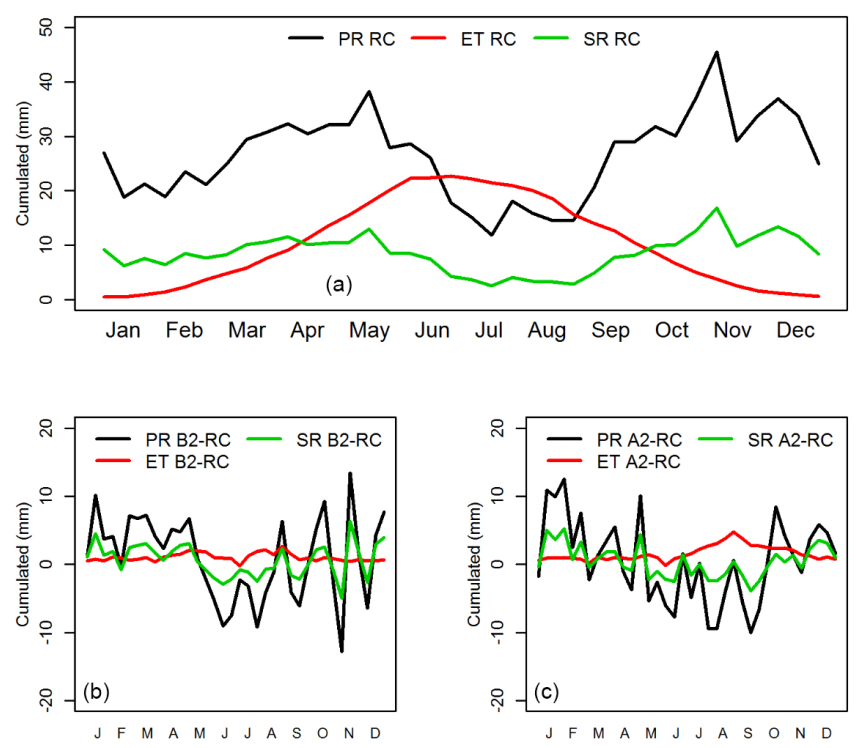

Figure 2. Annual cycles of the 10-day average values of the surface hydrologic budget components for the plain area for (a) RC, (b) $\mathrm{FC}_{\mathrm{B} 2}-\mathrm{RC}$, and (c) $\mathrm{FC}_{\mathrm{A} 2}-\mathrm{RC}$. Here, $\mathrm{PR}$ is precipitation, $\mathrm{ET}$ evapotranspiration, and SR surface runoff. Units are millimeters (mm).

October to March. In the summers of FCs, ET exceeds PR for a longer period (in $\mathrm{FC}_{\mathrm{A} 2}$ ), and both scenarios show larger water deficits in July and August, with the PR minimum shifted to August in $\mathrm{FC}_{\mathrm{A} 2}$ (not shown). Furthermore, the ET maxima shift towards July-August, in both $\mathrm{FC}_{\mathrm{A} 2}$ and $\mathrm{FC}_{\mathrm{B} 2}$ (not shown), and the values increase by as much as $3-5 \mathrm{~mm}$ (i.e., $\Delta \mathrm{ETs})$.

It is conspicuous that the summer PR decreases in the future - between the end of May and the beginning of September in $\mathrm{FC}_{\mathrm{B} 2}$ (Fig. 2b), and between July and September in $\mathrm{FC}_{\mathrm{A} 2}$ (Fig. 2c). On the contrary, PR generally increases in winter, between December and February, in both FCs. In autumn, $\triangle \mathrm{PRs}$ show large variations in short periods: for instance, in $\mathrm{FC}_{\mathrm{B} 2}$, it varies as much as $-6 \mathrm{~mm}$ in mid-September, $+10 \mathrm{~mm}$ in late September, $-12 \mathrm{~mm}$ in late October, $+15 \mathrm{~mm}$ in mid-November, and $-7 \mathrm{~mm}$ in late November. Regarding $\Delta \mathrm{ET}$, there are almost no variations in cold months, while there is a small increment (up to $3 \mathrm{~mm}$ ) between April and September in $\mathrm{FC}_{\mathrm{B} 2}$, and a larger increment in the same period in $\mathrm{FC}_{\mathrm{A} 2}$, with the largest value in August $(\sim 5 \mathrm{~mm})$. This large variation in PR is partly due to the orographic effect. As reported by Gao et al. (2006), in winter the southwesterly flow increases across the Alps, and causes a maximum of precipitation increase over the southern Alps; in autumn the main circulation change is in the easterly and southeasterly direction.

Figure 3 shows the 10-day mean values of SM for the plain area, expressed as saturation ratio - see Eq. (1). Variations of SM in plains are almost negligible in a colder period (late November-mid-May), but are large during a warmer period

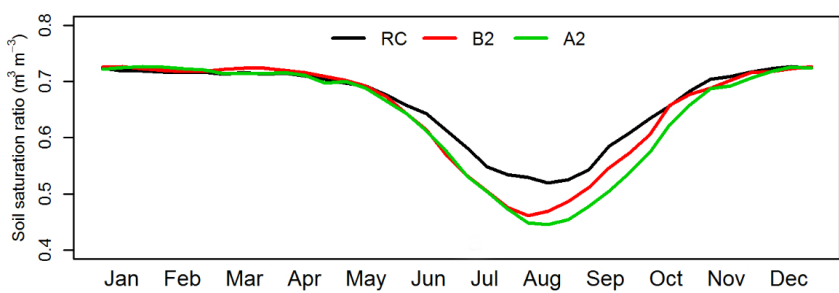

Figure 3. Annual cycles of the 10-day average values of SM, expressed as saturation ratio (in $\mathrm{m}^{3} \mathrm{~m}^{-3}$ ), at the soil surface layer (a depth of $0.05 \mathrm{~m}$ ) in $\mathrm{RC}, \mathrm{FC}_{\mathrm{B} 2}$, and $\mathrm{FC}_{\mathrm{A} 2}$ for the plain area.

(late May-mid-November): the driest points are antedated by $\sim 10$ days in FCs, still being in August, and their values decrease by $\sim 0.1 \mathrm{~m}^{3} \mathrm{~m}^{-3}$. The decrease begins already in spring (from late May) and continues till late October $\left(\mathrm{FC}_{\mathrm{B} 2}\right)$ or early November $\left(\mathrm{FC}_{\mathrm{A} 2}\right)$, with the largest depletion in early August $\left(\mathrm{FC}_{\mathrm{B} 2}\right)$ and in early to mid-August $\left(\mathrm{FC}_{\mathrm{A} 2}\right)$. Moreover, the period that future SM values are lower than the lowest $\mathrm{SM}$ of $\mathrm{RC}$ (i.e., $\sim 0.52 \mathrm{~m}^{3} \mathrm{~m}^{-3}$ in mid-August) extends from early July to early September in $\mathrm{FC}_{\mathrm{B} 2}$ and to mid-September in $\mathrm{FC}_{\mathrm{A} 2}$. In the driest periods of $\mathrm{FCs}$, several grid points in the plains go below their permanent wilting points (PWPs), which vary according to soil type, or remain below PWP for an excessive duration by about 1 month. Our results regarding the future changes in SM in the warm period - an increase in days of SM lower than the lowest SM of RC, and a surplus of period below PWP - signify that, if the land use of the grid points is pasture, we need appropriate countermeasures to ensure an adequate productivity. During the cold period in plains, SM shows the highest values $\left(\sim 0.73 \mathrm{~m}^{3} \mathrm{~m}^{-3}\right)$ in both $\mathrm{RC}$ and FCs; the SM values of FCs slightly exceed those in RC, due to the small increments of PR in this period (see Fig. 2b and c).

Figure 4 shows the annual cycle of hydrologic budget components over the high-mountain area $(h>2000 \mathrm{~m}$ a.s.l.). In both RC and FCs, PR does not exceed ET, while the gap between the two variables narrows in the FC summers, due to an increase in ET and a decrease in PR. In RC, ET peaks in mid-July while PR peaks in late June. The peak of SR, between May and June, is out of phase because it is also affected by the concurrent snowmelt. It is noteworthy that PRs in summer and autumn generally decrease in FCs (i.e., $\Delta \mathrm{PR}<0$ ) from mid-June to mid-November: except for short terms in early July, from mid- to late August, and from late September to late October in $\mathrm{FC}_{\mathrm{B} 2}$, and except only from early October to early November in $\mathrm{FC}_{\mathrm{A} 2}$. On the contrary, in winter and spring, PRs generally increase in FCs from mid-January to early June except for short-term decreases in mid-April and mid-May. Regarding $\Delta \mathrm{ET}$, there are almost no variations in cold months, as expected (due to snow cover), whereas there is a large increment $(\sim 10 \mathrm{~mm})$ between May and June, and a low-to-moderate increment $(\sim 2-6 \mathrm{~mm})$ between July and October in FCs. 
Finally, for $\Delta \mathrm{SR}$ in high mountains, there is a weak increase $(<5 \mathrm{~mm})$ between late November and late March, a stronger increment $(\sim 10 \mathrm{~mm})$ in April, especially in $\mathrm{FC}_{\mathrm{B} 2}$, a strong decrease (up to -25 to $-31 \mathrm{~mm}$ ) between May and June, and a general weak decrease in summer between July and September (see Fig. $4 \mathrm{~b}$ and c). As a result, the maxima of SR in FCs significantly decrease and their occurrence dates shift ahead to May for $\mathrm{FC}_{\mathrm{B} 2}$ and between April and May for $\mathrm{FC}_{\mathrm{A} 2}$ because snowmelt occurs nearly 30-40 days earlier (see Cassardo et al., 2018) - see also the analysis on frost frequency in Galli et al. (2010). Coppola et al. (2016) also reported that, regarding the 75th percentile in the Alpine areas, the snowmelt-driven runoff timing moves earlier by about 35 days - due to the largest decrease in snow cover between April and June, sustaining the spring runoff maximum. Those variations in our result are in line with the changes in snowpack in FCs, which starts to melt earlier, between late April and early May. We should consider that changes in snow cover affect the surface energy budget through the snow-albedo feedback mechanism (Giorgi et al., 1997); that is, a reduction of snow cover decreases the surface albedo and thus increases the absorption of solar radiation at the surface, resulting in warming. Moreover, soil temperature starts rising earlier in the year in the snowless areas. Our results also agree with other studies, carried out using RCMs over the Alpine areas: for example, Lautenschlager et al. (2008) for PR and ET, and Jacob et al. (2007b) for snow. Note that SR in RC is almost null between mid-December and March while $\Delta$ SRs in FCs in the same period are positive: this indicates the presence of rainfall and/or snowmelt over at least some parts of the high-mountain grid points, even in the coldest periods.

Figure 5 shows SM at the high-mountain grid points and demonstrates the effects of hydrologic budget components on surface SM. We note that the behaviors of SM in high mountains are substantially different from those over plains (cf. Fig. 3). In RC, the highest SM $\left(\sim 0.65 \mathrm{~m}^{3} \mathrm{~m}^{-3}\right)$ occurs in early June while the lowest SM $\left(\sim 0.51 \mathrm{~m}^{3} \mathrm{~m}^{-3}\right)$ arises in early to mid-March. The increase in SM from late March to early June is related to snowmelt due to an increase in net radiation. Surface SM in RC starts to decrease as the cold season starts in early November, reaching the minimum in mid-March. Note that SMs during the same cold period in FCs are larger than SM in RC, evidencing a larger amount of liquid precipitation in FCs: in other words, winter rainfall will be more frequent in the future. The peak of SM in spring is advanced by 10-20 days in FCs, occurring in early May. The magnitude of maximum SM in FCs is a bit lower than that in RC but the spread is larger, implying that snow ablation starts much earlier and lasts longer. In addition, the occurrence of the minimum SR shifts from mid-March in RC to summer in FCs: in both February and early August (i.e., two minima) in $\mathrm{FC}_{\mathrm{B} 2}$, and late August in $\mathrm{FC}_{\mathrm{A} 2}$. This shifting is mainly caused by the enhancement of ET.
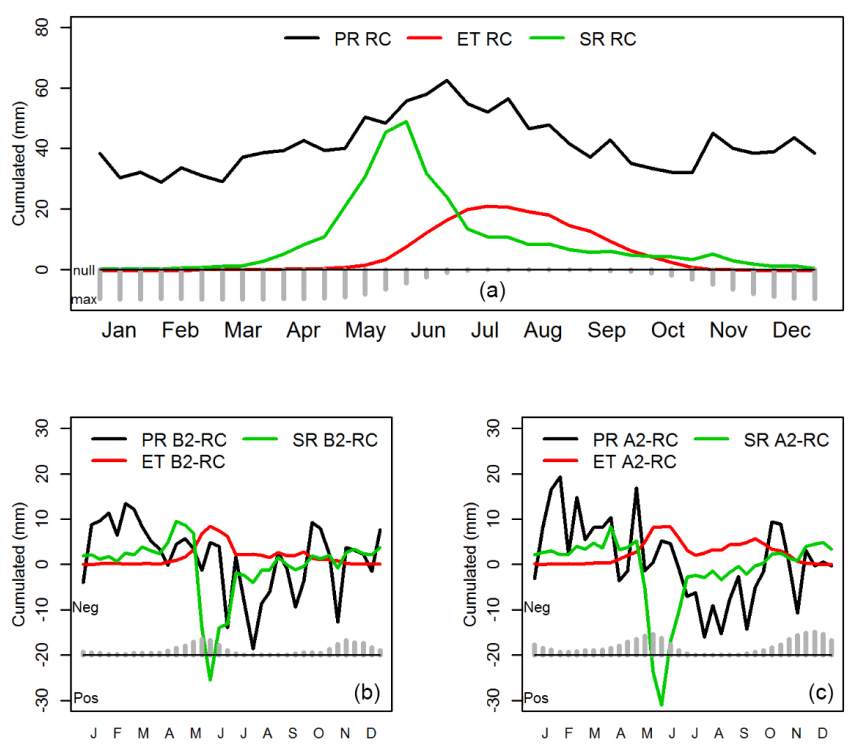

Figure 4. Same as in Fig. 2 but for the high-mountain area. Grey bars at the lower portion in (a) represent the snow cover (in $\mathrm{m}$ ) in RC varying from $0 \mathrm{~m}$ (null) to $1 \mathrm{~m}(\max )$; in (b) and (c) the snow cover difference (in $\mathrm{m}$ ) between the corresponding $\mathrm{FC}$ and $\mathrm{RC}$ varies from $-1 \mathrm{~m}$ (Neg) to $1 \mathrm{~m}$ (Pos). The periods of snow ablation (late spring) and accumulation (mid or late autumn) are well identified.

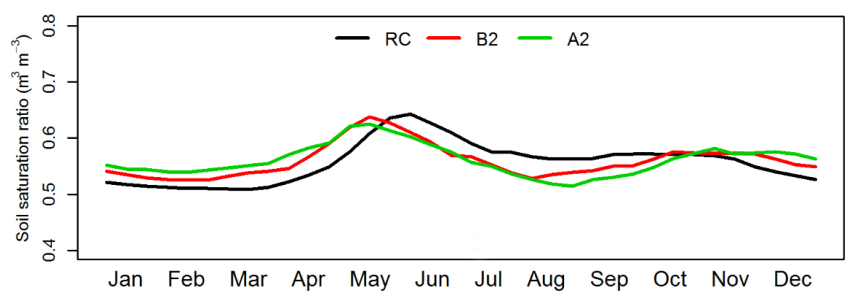

Figure 5. Same as in Fig. 3 but for the high-mountain area.

\subsection{Spatial distribution of evapotranspiration, precipitation, runoff and soil moisture}

Our analyses illustrate that the differences in the SM behaviors between RC and FC, both over plains (Fig. 3) and in high mountains (Fig. 5), are strongly linked to the variations in the hydrologic budget components. In this section, to understand such linkage more clearly, we perform analyses on the spatial distribution of hydrologic variables (i.e., PR, ET, $\mathrm{SR}$, and surface SM) along with discussions on the associated energy variables (i.e., net radiation, NR, and surface soil temperature, ST), during summer when such variables generally show their largest values. Details in the analyses of NR and ST are referred to Cassardo et al. (2018).

Figure 6 shows the variables averaged in the month of July, in which PR and surface SM are close to their annual minima while ET is close to its annual maximum. Here, we discuss the variables in terms of anomalies of $\mathrm{FC}_{\mathrm{A} 2}$ only because of similar patterns to but larger variations than those of $\mathrm{FC}_{\mathrm{B} 2}$. 
Variables in Fig. 6 are anomalies of hydrologic budget components: $\Delta \mathrm{ET}, \triangle \mathrm{PR}, \Delta \mathrm{SR}$, and $\Delta \mathrm{SM}$ where, e.g., $\Delta \mathrm{ET}$ represents $\mathrm{ET}_{\mathrm{FC}_{\mathrm{A} 2}}-\mathrm{ET}_{\mathrm{RC}}$.

Compared to $\mathrm{RC}$, we notice a large increment of NR everywhere in $\mathrm{FC}_{\mathrm{A} 2}$ (not shown), with the exception of a few grid points located in the central and western Alps. Regarding $\triangle \mathrm{ET}$ (Fig. 6a), plains along the Po River and the northern off-alpine regions (i.e., middle-slope and/or foot) show the largest increments, well correlated to $\triangle \mathrm{NR}$, implying that most of the available energy excess is used for evaporative processes. In contrast, in the Apennines and central Alps, $\Delta \mathrm{ETs}$ are almost null or slightly negative while $\Delta \mathrm{NRs}$ are insignificantly positive. $\Delta \mathrm{PR}$ (Fig. 6b) and $\Delta \mathrm{SR}$ (Fig. 6c) show similar signals, with a general deficit, especially in the eastern and western Alpine areas. In particular, consistent with Coppola et al. (2016), $\triangle \mathrm{PR}$ depicts a dipolar pattern, especially in the eastern part of the Italian Alps, with positive values over the Alps and its north and negative values over south of the Alps. Surface $\triangle \mathrm{SM}$ (Fig. 6d) shows a general reduction, larger in the zones at latitudes lower than $45^{\circ} \mathrm{N}$, whereas surface $\Delta \mathrm{ST}$ (not shown) is almost uniformly larger in the considered domain. As ETs increase (i.e., $\Delta \mathrm{ET}>0$ ), SMs generally decrease; however, both decrease over some regions where $\triangle \mathrm{SMs}$ are strongly negative - on the western mountainous Emilia-Romagna region and Tuscany, and along the Po River and in central and southern Piedmont as well (cf. Fig. 6a and d). When SM decreases below the wilting point, evaporation generally ceases because there is no available water for further ET, and the ET anomaly (i.e., $\triangle \mathrm{ET}$ ) can be negative. Considering that most of those areas are important for agricultural production (see, e.g., Prino et al., 2009, a study on grapevine in Piedmont region), our results constitute a threatening challenge for future agricultural productivity.

It is evident that $\triangle \mathrm{ET}$ and $\triangle \mathrm{PR}$ do not show a linear correlation (cf. Fig. 6a and b). $\Delta$ ETs are generally positive, whereas $\triangle \mathrm{PRs}$ are distributed around null with some positive peaks on the Apennines and northwestern Italy and large negative peaks on some Alpine locations. This disparity brings about and/or enhances the nonlinear interactions among temperature, evaporation, soil moisture, etc. Noting that nonlinearity can develop even with small perturbations (e.g., Park, 1999), our results elucidate that similar investigations can only be conducted using models that are able to give a correct estimation of energy and hydrologic processes.

\subsection{Number of dry and wet days in the future climate}

The availability of the SM estimations enables us to evaluate the occurrence of dry and wet days, instead of using atmospheric relative humidity as usual, in a similar way to figure the warm and cold days via the ST estimations. We employ SM to assess the dry and wet days in FCs because we consider it to be a more valuable indicator of the soil hydrologic conditions, directly reflecting the hydrologic status of the soil water, e.g., that used by plants. Here, we limit the analysis to the surface SM (i.e., in the top soil layer with a depth of $5 \mathrm{~cm}$ ), due to its significant impact on several agricultural productions.

Actually, for the short grass vegetation category considered in our simulations, the root layer is only $5 \mathrm{~cm}$ deep, as the grass is only $10 \mathrm{~cm}$ high. Despite this value seeming too low, it represents the typical height for the landscapes of Po Valley (at least in its portion occupied by natural vegetation). Furthermore, the upper soil layer represents the greatest effect of the atmosphere-land surface-soil interactions. Given that we are interested in the present versus future hydrologic budget components, it is appropriate to focus on the top soil layer, where the most dynamic interactions with atmosphere and land surface occur. More specifically, the water content of the soil layer that represents the largest variations of moisture is subject to direct evaporation; to the transpiration from vegetation roots; to the gravitational drainage to the second soil layer; to the capillary suck of moisture from the second soil layer; and finally to the eventual precipitation, eventual vegetation drainage, and eventual snow runoff.

In order to find the absolute thresholds for SM, we have selected two parameters: PWP and the field capacity. PWP is the SM level below which the osmotic pressure of the plant roots is insufficient to extract water from the soil, and is usually considered as an indicator of a serious water deficit for agricultural practices. The field capacity represents the SM level above which the gravitational drainage, due to soil hydraulic conductivity, causes a rapid removal of the excess water through percolation into deeper layers; thus, it is considered to be a threshold above which soil is very wet, as in the cases of very intense precipitation, sometimes causing floods. Since these two values change according to the soil type and texture, we define a non-dimensional index, $Q_{I}$, which is independent from soil type, as follows:

$$
Q_{I}=\frac{q_{1}-q_{\mathrm{wi}}}{q_{\mathrm{fc}}-q_{\mathrm{wi}}},
$$

where $q_{1}$ is the moisture of the top soil layer, $q_{\text {wi }}$ is PWP, and $q_{\mathrm{fc}}$ is the field capacity. All the values are expressed as a soil saturation ratio. In this way, the soil wetness is categorized in terms of $Q_{I}$ as extremely dry soil for $Q_{I} \leq 0$, and extremely wet soil for $Q_{I} \geq 1$. In this study, we define the thresholds for dry soil and wet soil as $Q_{I}=0$ and $Q_{I}=0.8$, respectively. Note that it is quite rare to see the cases with $Q_{I}=1$ because the 3-hourly precipitation data from $\mathrm{RegCM} 3$ are interpolated to hourly data by keeping the constant rain rate, to be used as input for UTOPIA. Therefore, we have arbitrarily defined the threshold for wet soil as $Q_{I}=0.8$.

Figure 7 shows the anomalies of dry and wet days in $\mathrm{FC}_{\mathrm{A} 2}$. The number of dry days generally increases in most of the domain except the Alpine high-mountain areas (Fig. 7a). A higher number of dry days (e.g., 30-50 days) occur over the regions of extreme soil dryness - the coastal areas as well as the off-alpine regions of the Alps and the Apennines (cf. 

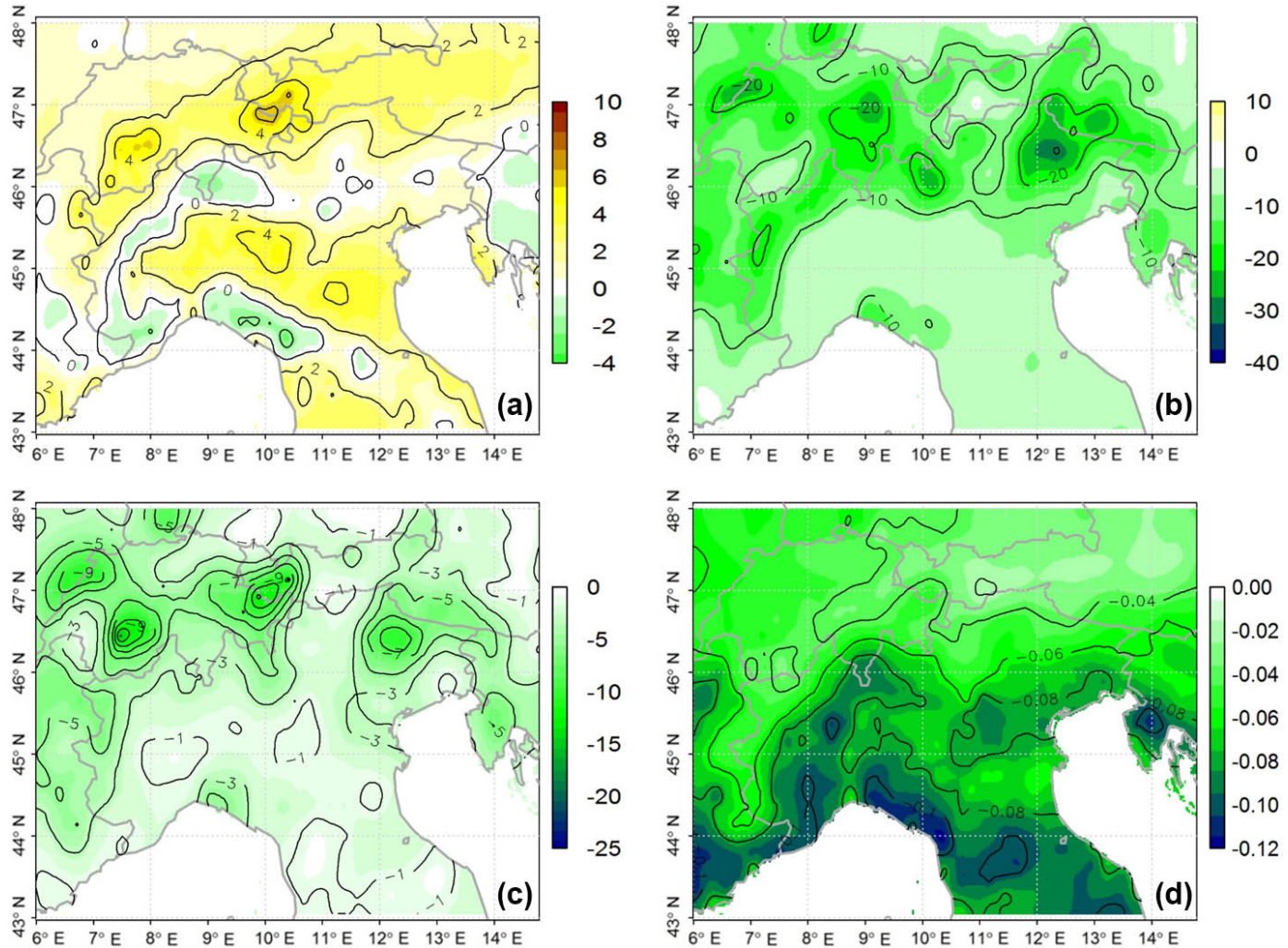

Figure 6. Hydrologic budget components: differences between $\mathrm{FC}_{\mathrm{A} 2}$ and $\mathrm{RC}$ (i.e., $\mathrm{FC}_{\mathrm{A} 2}-\mathrm{RC}$ ) of the mean values of (a) $\mathrm{ET}$ (in mm), (b) $\mathrm{PR}$ (in $\mathrm{mm}$ ), (c) SR (in $\mathrm{mm}$ ), and (d) surface SM (in $\mathrm{m}^{3} \mathrm{~m}^{-3}$ ). The mean is calculated over the month of July.

Fig. 6d). The interannual variability of the dry-day occurrence also decreases (not shown), implying that our results are relatively robust and that we may experience drought over the non-high-mountain areas in almost every year.

The number of wet days, on the other hand, is almost stationary over plains but increases by 10-15 days in some localized regions close to the Alps in the Italian side (especially in the Lombardy region), and by even more than 20 days at the feet of the Alps in Switzerland, France, and Austria (Fig. 7b). The interannual variability is generally stationary, but increases in the areas with the largest numbers of wet days (not shown). Therefore, in $\mathrm{FC}_{\mathrm{A} 2}$, we can have more occasions of reaching high values of surface SM, and hence a potentially higher risk of floods. This also implicates a corresponding higher possibility of hydrogeological instability over the same areas of higher flood risk.

Overall, in the plain areas including the Po Valley, $\Delta \mathrm{ET}$ is positive while $\triangle \mathrm{PR}$ is weakly negative and $\Delta \mathrm{SM}$ is moderately negative (especially during summer, as in Figs. 2 and 3 ). With more significant overall increases in NR over plains, the combined effect will bring about larger evaporation and lower soil moisture, and thus an overall increase in the number of dry days, mostly attributed to a much drier climate in summer. Meanwhile, over the high-mountain areas, PR, SR, and SM increase while ET shows little variation in spring and winter (see Figs. 4 and 5). As SM is large over high mountains, we have more source of atmospheric moisture through evaporation there. Then, through the combined effect of terrain-induced convective motion, increase in NR (though less significant), and pre-existing snow, we can have more snowmelt (during spring) and more liquid precipitation (especially during winter), resulting in more wet days, again mostly attributed to much a wetter climate in winter.

\subsection{Comparative discussion on previous works}

The Mediterranean basin is recognized as one of the climatic hotspots around the world (Giorgi, 2006; Diffenbaugh and Giorgi, 2012; Gobiet et al., 2014; Vautard et al., 2014; Paeth et al., 2017). The Alps and their adjacent areas, including the Po River basin in Italy, have been a target region of many climate projection studies, using either a single RCM or an ensemble of GCMs and/or RCMs (e.g., to mention just a few, Gao et al., 2006; Giorgi and Lionello, 2008; Im et al., 2010; Dobler et al., 2012; Shaltout and Omstedt, 2014; Addor et al., 2014; Coppola et al., 2014, 2016; Gobiet et al., 2014; Torma et al., 2015; Frei et al., 2018).

In general, those studies showed good agreements with our results and produced consistent results of climate projections at the end of 21 st century over the study region. However, 

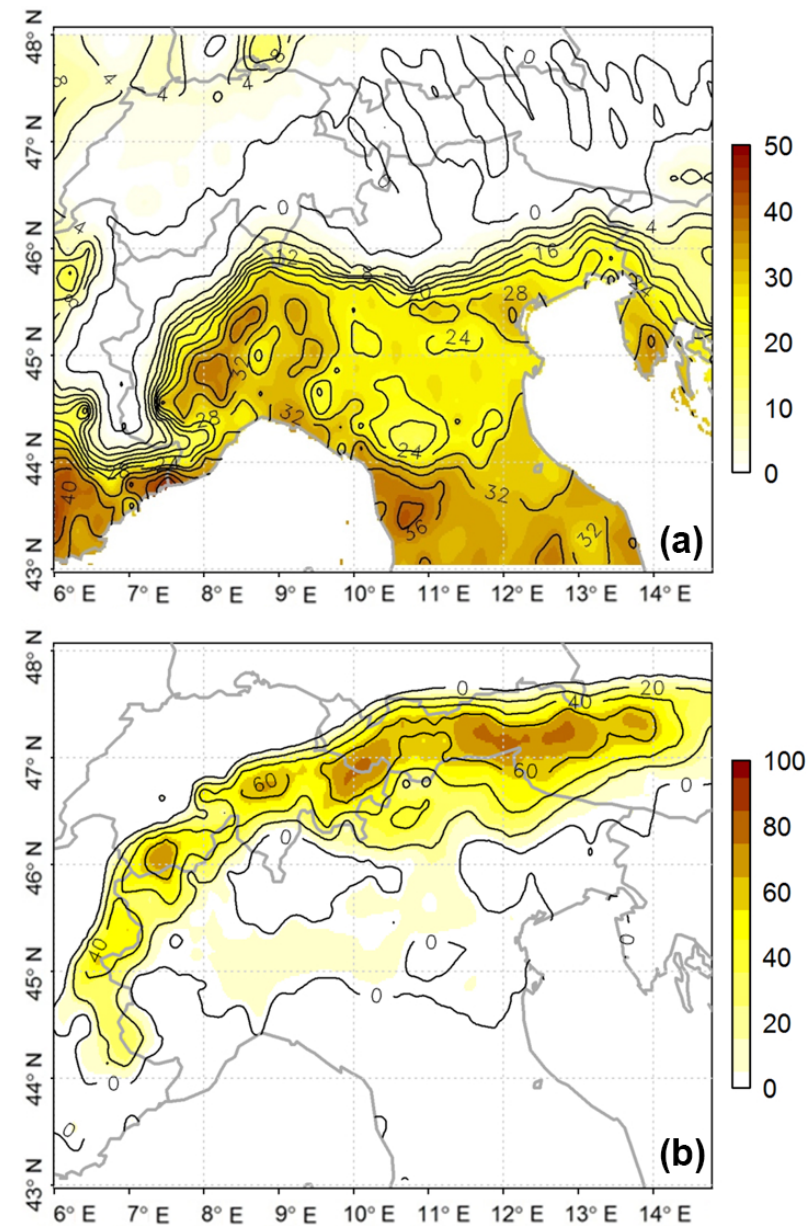

Figure 7. The anomalies in number of (a) dry days and (b) wet days in $\mathrm{FC}_{\mathrm{A} 2}$.

none of them studied hydroclimate projections of the full water cycle by assessing all hydrologic components - precipitation, evapotranspiration, runoff, and soil moisture - as in our study. Most them focused on just some specific component(s) of the water cycle, e.g., precipitation and/or surface runoff. For instance, Giorgi and Lionello (2008) studied climate change projections for the Mediterranean region, focusing on precipitation and temperature; Coppola et al. (2014) studied the impact of climate change on the Po basin, addressing discharge; and Torma et al. (2015) carried out ensemble RCM projections over the Alps, focusing on precipitation.

Nevertheless, it is meaningful to compare our findings, on overall hydrologic components, with other studies over the same study area. Basically, most of the previous studies showed consistent results with ours, as shown in the following. Gao et al. (2006) illustrated the positive anomaly of precipitation in the future climate over the southern Alps from autumn through spring, and the negative anomaly in summer over the highest peaks of the Alps. Giorgi and Lionello
(2008) remarked on the peculiar behavior of the Alpine region, compared to the Mediterranean basin, with moderate drying during warmer seasons and an increase in precipitation in winter, and a large increment of interannual variability, which can lead to an increase in extreme events such as droughts and floods. Im et al. (2010) discussed a surrogate climate change simulation over the Alpine region and found that the winter precipitation increased with a significant dependence on elevation while the summer precipitation decreased over the Alpine mountain chain, due to a local surface-atmosphere feedback mechanism involving reduced snow cover and soil moisture at the beginning of summer. Dobler et al. (2012) showed that future precipitation decreased during summer and increased during winter and spring over the Alps; Shaltout and Omstedt (2014) also noted the increment of winter precipitation in the future climate in the Alpine region, due to a negative correlation with decreasing pressure patterns. Addor et al. (2014) addressed the larger changes in the precipitation regime in the higherelevation Alpine catchments. Coppola et al. (2014) examined the variation in the discharge maxima of the Po River in the future climate, and concluded that the winter-spring maximum would increase and the summer-autumn maximum will decrease. Torma et al. (2015) confirmed that future precipitation would increase (decrease) over northern (southern) Europe, with most of the Alpine region exhibiting a positive (negative) precipitation change in the winter (summer). Frei et al. (2018) found a robust signal of decreasing snowfall amounts, from September to May, over most parts of the Alps, with relative changes in mean snowfall being strongly dependent on elevation. In a review paper based on the existing literature and additional analyses on climate change in the Alps, Gobiet et al. (2014) concluded that warming induces a seasonal precipitation change - increase in winter and decrease in summer - and a drastic decrease in snow cover below $1500-2000 \mathrm{~m}$ in the Alps.

Compared to most other studies, which focused on the subcomponent(s) of hydrologic cycle, our study is quite exhaustive and has its own uniqueness: our study provides more complete analyses on all hydrologic components, including soil moisture, for both the reference climate and future projections. Furthermore, along with a study on the land surface energy balance (Cassardo et al., 2018), we provide discussions on the linkages between the hydrologic and energy components to complete the full description of hydroclimatic changes. These enable us to better quantify some significant variations in the frame of changing climate in the Alpine and adjacent areas, in which the climatic change shows a larger variability. 


\section{Conclusions}

In this study, we investigated the characteristic changes in hydrologic budget components and soil moisture, over the Alpine areas and northern Italy, under the projected conditions of the future climate (FC; 2071-2100), compared to the reference climate (RC). We employed the University of TOrino model of land Processes Interaction with Atmosphere in offline simulations. The meteorological input data in FCs are provided by the Regional Climate Model version 3 , based on the A2 and B2 scenarios from the Intergovernment Panel on Climate Change Special Report on Emissions Scenarios.

In $\mathrm{FCs}$ based on the $\mathrm{A} 2$ and $\mathrm{B} 2$ scenarios $\left(\mathrm{FC}_{\mathrm{A} 2}\right.$ and $\mathrm{FC}_{\mathrm{B} 2}$, respectively), the most significant changes are the increment of evapotranspiration (ET) and the subsequent depletion of soil moisture (SM), more remarkably in $\mathrm{FC}_{\mathrm{A} 2}$. Precipitation (PR) shows the lowest values while ET depicts the highest values in the future summer (in particular, July), when SMs are the lowest in many grid points. In the plain area, the minimum SM in FC occurs about 20-30 days earlier than in RC, and remains low for the successive months up to November. In the high-mountain area, the surface runoff (SR) coming from the snowmelt keeps the soil water amount sufficiently high to maintain the ET levels high from May to October, especially in $\mathrm{FC}_{\mathrm{A} 2}$; thus, ET (or latent heat flux) always exceeds sensible heat flux (SHF). Over plains, the period in which ET exceeds PR elongates by about 1 month, mainly in spring. Moreover, SM decreases also for one more month in summer, falling below the wilting point threshold in the surface soil layer. In high mountains, due to the earlier occurrence of snowmelt, the land surface becomes snowless for an additional month.

We found that these changes in the hydrologic budget components are strongly related to the variations of net radiation (NR), which generally increase in the Alpine area, causing the warming of both the top soil layer and the soil surface - the former through an enhanced SHF, and the latter due to the highest soil heat flux (see, e.g., Cassardo et al., 2018). Under the future conditions of increasing NR and soil temperature along with decreasing SM, we expect two climatic feedbacks to take place: (1) a drier soil brings about higher albedo, and (2) a warmer soil emits more longwave radiations. Both feedbacks act to decrease NR eventually i.e., negative feedbacks. However, there are coincident increments of SHF to the atmosphere as well as longwave radiation emitted by the warmer atmosphere. The overall outcome cannot be generalized because it depends on the intensity of individual component of the energy and hydrologic budgets. This confirms that the climate system is quite complex and that, to evaluate well the surface conditions, it is essential to calculate the energy and hydrologic budget components in detail.

The values presented in this study refer only to the average conditions; however, considering the large interannual vari- ability of hydrologic variables registered over those areas in $\mathrm{RC}$, we expect to have more frequent and more intense occurrences of longer dry spells (hence severe droughts) and heat waves in FCs, especially in middle summers. As most agricultural products intensively grow in summer (e.g., wheat, rice, maize, and grapevine, as well as other typical products in the Po valley), the potential conditions of elongated drought will significantly exert unfavorable impacts on agricultural production (Bocchiola et al., 2013). Other activities related to water supply (e.g., industry, hydroelectric power production, etc.) can also suffer serious problems, consequently exerting harmful impacts on economy and human health in local regions.

On the contrary, during winter, PRs generally increase in FCs, with a larger number of the liquid precipitation events at high elevations. Furthermore, in spring, snowmelt occurs earlier by about 1 month, thus resulting in precedence of the SR peak by about 20-30 days. In winter, the SR amount generally increases. By taking into account the large interannual variability of $P R$, this runoff increases the occurrence and/or duration of wet periods (e.g., heavy rainfall and floods) during winter and spring in FCs.

We also examined potential changes in the number of dry and wet days in $\mathrm{FC}_{\mathrm{A} 2}$ by analyzing surface SMs. Our results report a higher possibility of having SMs below the wilting point in the plain and coastal areas, and a probability of slightly increasing wet days, particularly in the off-alpine areas.

We note that the numerical values of all variables are dependent on the performance of the model employed. Noting that our study is based on a single-model approach, uncertainties in the projected changes related to model bias and ensemble variability can be large; thus, our results should be interpreted with caution. In this context, further research is needed to obtain more robust results from an ensemble approach.

Recent studies demonstrate that the accuracy of land surface processes diagnosed by land surface models can be further improved by considering various aspects of vegetation effects in the subgrid-scale parameterizations (e.g., Park and Park, 2016; Gim et al., 2017). Moreover, the model uncertainties can be significantly reduced by optimal estimation of the parameter values in the schemes (e.g., Lee et al., 2006; Yu et al., 2013) and/or seeking for an optimized set among multiple-physics optional schemes (e.g., Hong et al., 2014, 2015). By applying these methods, the details of modelgenerated spatial and temporal changes in the future energy and hydrologic budgets can be different from the current results; however, we believe that the general trends are not significantly disparate. Overall, our findings can provide a useful guideline to plan the managements of water resources, floods, irrigation, forestry, hydropower, and many other activities relevant for human life. 
Data availability. The ECOCLIMAP data are available online from https://opensource.umr-cnrm.fr/projects/ecoclimap/files (Masson et al., 2003).

Competing interests. The authors declare that they have no conflict of interest.

Acknowledgements. The authors acknowledge the Earth System Physics Section of the ICTP, Italy, for providing the RegCM3 dataset. Sungmin $\mathrm{O}$ was partly supported by the University of Torino (UNITO) for visiting its Department of Physics under the World Wide Style grant. Claudio Cassardo and Seon Ki Park are supported by the governments of Italy and Korea, respectively, for visiting each institution for collaborative research via the bilateral scientific agreements. This work was partly supported by the National Research Foundation grant (no. 2009-0083527) funded by the Korean government (MSIP). The work is partially done during a sabbatical leave by Seon Ki Park to UNITO in 2017.

Edited by: Alexander Gelfan

Reviewed by: three anonymous referees

\section{References}

Abiodun, B. J., Pal, J. S., Afiesimama, E. A., Gutowski, W. J., and Adedoyin, A.: Simulation of West African Monsoon using RegCM3. Part II: Impact of desertification and deforestation, Theor. Appl. Climatol., 93, 245-261, 2007.

Adam, J. C., Hamlet, A. F., and Lettenmaier, D. P.: Implications of global climate change for snowmelt hydrology in the twenty-first century, Hydrol. Process., 23, 962-972, 2009.

Addor, N., Rössler, O., Köplin, N., Huss, M., Weingartner, R., and Seibert, J.: Robust changes and sources of uncertainty in the projected hydrological regimes of Swiss catchments, Water Resour. Res., 50, 7541-7562, https://doi.org/10.1002/2014WR015549, 2014.

Alo, C. A. and Anagnostou, E. N.: A sensitivity study of the impact of dynamic vegetation on simulated future climate change over Southern Europe and the Mediterranean, Int. J. Climatol., 37, 2037-2050, https://doi.org/10.1002/joc.4833, 2017.

Anthes, R.: A cumulus parametrization scheme utilizing a onedimensional cloud model, Mon. Weather Rev., 105, 270-286, 1977.

Araújo, M. B., Nogués-Bravo, D., Reginster, I., Rounsevell, M., and Whittaker, R. J.: Exposure of European biodiversity to changes in human-induced pressures, Environ. Sci. Policy, 11, 38-45, https://doi.org/10.1016/j.envsci.2007.07.002, 2008.

Ayers, M. A., Wolock, D. M., McCabe, G. J., and Hay, L. E.: Hydrologic effects of climatic change in the Delaware River basin, in: US Geological Survey Yearbook, Fiscal Year 1989, US Government Printing Office, Washington, DC, USA, 31-33, 1990.

Baker, N. C. and Huang, H.-P.: A comparative study of precipitation and evaporation between CMIP3 and CMIP5 climate model ensembles in semiarid regions, J. Climate, 27, 3731-3749, https://doi.org/10.1175/JCLI-D-13-00398.1, 2014.
Ballester, J., Rodó, X., and Giorgi, F.: Future changes in Central Europe heat waves expected to mostly follow summer mean warming, Clim. Dynam., 35, 1191-1205, https://doi.org/10.1007/s00382-009-0641-5, 2010.

Barange, M., Merino, G., Blanchard, J. L., Scholtens, J., Harle, J., Allison, E. H., Allen, J. I., Holt, J., and Jennings, S.: Impacts of climate change on marine ecosystem production in societies dependent on fisheries, Nature Clim. Change, 4, 211-216, https://doi.org/10.1038/nclimate2119, 2014.

Belda, M., Skalák, P., Farda, A., Halenka, T., Déqué, M., Csima, G., Bartholy, J., Torma, C., Boroneant, C., Caian, M., and Spiridonov, V.: CECILIA regional climate simulations for future climate: Analysis of climate change signal, Adv. Meteorol., 2015, 354727, https://doi.org/10.1155/2015/354727, 2015.

Beniston, M.: Mountain weather and climate: A general overview and a focus on climatic change in the Alps, Hydrobiologia, 562, 3-16, https://doi.org/10.1007/s10750-005-1802-0, 2006.

Beniston, M.: Trends in joint quantiles of temperature and precipitation in Europe since 1901 and projected for 2100, Geophys. Res. Lett., 36, L07707, https://doi.org/10.1029/2008GL037119, 2009.

Beniston, M., Stephenson, D. B., Christensen, O. B., Ferro, C. A. T., Frei, C., Goyette, S., Halsnaes, K., Holt, T., Jylhü, K., Koffi, B., Palutikoff, J., Schöll, R., Semmler, T., and Woth, K.: Future extreme events in European climate: an exploration of regional climate model projections, Clim. Change, 81, 71-95, https://doi.org/10.1007/s10584-006-9226-z, 2007.

Berg, P., Moseley, C., and Haerter, J. O.: Strong increase in convective precipitation in response to higher temperatures, Nat. Geosci., 6, 181-185, https://doi.org/10.1038/ngeo1731, 2013.

Bhaskaran, B., Ramachandran, A., Jones, R., and MoufoumaOkia, W.: Regional climate model applications on sub-regional scales over the Indian monsoon region: The role of domain size on downscaling uncertainty, J. Geophys. Res., 117, D10113, https://doi.org/10.1029/2012JD017956, 2012.

Blenkinsop, S. and Fowler, H. J.: Changes in European drought characteristics projected by the PRUDENCE regional climate models, Int. J. Climatol., 27, 1595-1610, https://doi.org/10.1002/joc.1538, 2007.

Boberg, F., Berg, P., Thejll, P., Gutowski, W. J., and Christensen, J. H.: Improved confidence in climate change projections of precipitation evaluated using daily statistics from the PRUDENCE ensemble, Clim. Dynam., 32, 1097-1106, https://doi.org/10.1007/s00382-008-0446-y, 2009.

Bocchiola, D., Nana, E., and Soncini, A.: Impact of climate change scenarios on crop yield and water footprint of maize in the Po valley of Italy, Agr. Water Manage., 116, 50-61, 2013.

Bonanno, R., Loglisci, N., Cavalletto, S., and Cassardo, C.: Analysis of different freezing/thawing parameterizations using the UTOPIA model, Water, 2, 468-483, 2010.

Bultot, F., Coppens, A., Dupriez, G. L., Gellens, D., and Meulenberghs, F.: Repercussions of a $\mathrm{CO}_{2}$ doubling on the water cycle and on the water balance - a case study for Belgium, J. Hydrol., 99, 319-347, 1988.

Buonomo, E., Jones, R., Huntingford, C., and Hannaford, J.: On the robustness of changes in extreme precipitation over Europe from two high resolution climate change simulations, Q. J. R. Meteor. Soc., 133, 65-81, https://doi.org/10.1002/qj.13, 2007. 
Burden, R. L. and Faires, J. D.: Numerical Analysis, Brooks/Cole, Boston, MA, USA, 2004.

Buytaert, W., Celleri, R., and Timbe, L.: Predicting climate change impacts on water resources in the tropical Andes: Effects of GCM uncertainty, Geophys. Res. Lett., 36, L07406, https://doi.org/10.1029/2008GL037048, 2009.

Cabré, M. F., Solman, S. A., and Nunez, M. N.: Regional climate change scenarios over southern South America for future climate (2080-2099) using the MM5 model. Mean, interannual variability and uncertainties, Atmósfera, 29, 35-60, https://doi.org/10.20937/ATM.2016.29.01.04, 2016.

Calzadilla, A., Rehdanz, K., Betts, R., Falloon, P., Wiltshire, A., and Tol, R. S. J.: Climate change impacts on global agriculture, Clim. Change, 120, 357-374, https://doi.org/10.1007/s10584013-0822-4, 2013.

Carvalho, A., Monteiro, A., Solman, S., Miranda, A. I., and Borrego, C.: Climate-driven changes in air quality over Europe by the end of the $21 \mathrm{st}$ century, with special reference to Portugal, Environ. Sci. Policy, 13, 445-458, https://doi.org/10.1016/j.envsci.2010.05.001, 2010.

Casajus, N., Périé, C., Logan, T., Lambert, M.-C., de Blois, S., and Berteaux, D.: An objective approach to select climate scenarios when projecting species distribution under climate change, PLoS ONE, 11, e0152495, https://doi.org/10.1371/journal.pone.0152495, 2016.

Cassardo, C.: The land surface process model (LSPM) version 2006, Tech. Rep. DFG Report - 01/2006, Dipartimento di Fisica Generale Amedeo Avogadro, University of Torino, Torino, Italy, 2006

Cassardo, C.: The University of TOrino model of land Process Interaction with Atmosphere (UTOPIA) version 2015, Tech. Rep., CCCPR/SSRC-TR-2015-1, CCCPR/SSRC, Ewha Womans University, Seoul, Republic of Korea, 2015.

Cassardo, C., Ji, J. J., and Longhetto, A.: A study of the performances of a land surface process model (LSPM), Bound.-Lay. Meteorol., 72, 87-121, 1995.

Cassardo, C., Ruti, P. M., Cacciamani, C., Longhetto, A., Paccagnella, T., and Bargagli, A.: CLIPS experiment. First step: model intercomparison and validation against experimental data, MAP Newsletters, 7, 74-75, 1997.

Cassardo, C., Carena, E., and Longhetto, A.: Validation and sensitivity tests on improved parametrizations of a land surface process model (LSPM) in the Po Valley, Il Nuovo Cimento, 21, 189213, 1998.

Cassardo, C., Loglisci, N., Gandini, D., Qian, M. W., Niu, Y. P., Ramieri, P., Pelosini, R., and Longhetto, A.: The flood of November 1994 in Piedmont, Italy: A quantitative simulation, Hydrol. Process., 16, 1275-1299, 2002.

Cassardo, C., Loglisci, N., and Romani, M.: Preliminary results of an attempt to provide soil moisture datasets in order to verify numerical weather prediction models, Il Nuovo Cimento, 28, 159171,2005

Cassardo, C., Loglisci, N., Paesano, G., Rabuffetti, D., and Qian, M. W.: The hydrological balance of the October 2000 flood in Piedmont, Italy: Quantitative analysis and simulation, Phys. Geogr., 27, 411-434, 2006.

Cassardo, C., Mercalli, L., and Cat Berro, D.: Characteristics of the summer 2003 heat wave in Piedmont, Italy, and its effects on water resources, J. Korean Meteor. Soc., 43, 195-221, 2007.
Cassardo, C., Park, S. K., Thakuri, B. M., Priolo, D., and Zhang, Y.: Soil surface energy and water budgets during a monsoon season in Korea, J. Hydrometeorol., 10, 1379-1396, 2009.

Cassardo, C., Park, S. K., O, S., and Galli, M.: Projected changes in soil temperature and surface energy budget components over the Alps and northern Italy, Water, in review, 2018.

Christensen, J. H. and Christensen, O. B.: A summary of the PRUDENCE model projections of changes in European climate by the end of this century, Clim. Change, 81, 7-30, https://doi.org/10.1007/s10584-006-9210-7, 2007.

Christensen, J. H., Carter, T. R., Rummukainen, M., and Amanatidis, G.: Evaluating the performance and utility of regional climate models: the PRUDENCE project, Clim. Change, 81, 1-6, https://doi.org/10.1007/s10584-006-9211-6, 2007.

Ciscar, J.-C., Iglesias, A., Feyen, L., Szabó, L., Van Regemorter, D., Amelung, B., Nicholls, R., Watkiss, P., Christensen, O. B., Dankers, R., Garrote, L., Goodess, C. M., Hunt, A., Moreno, A., Richards, J., and Soria, A.: Physical and economic consequences of climate change in Europe, P. Natl. Acad. Sci. USA, 108, 26782683, https://doi.org/10.1073/pnas.1011612108, 2011.

Coppola, E. and Giorgi, F.: An assessment of temperature and precipitation change projections over Italy from recent global and regional climate model simulations, Int. J. Climatol., 30, 11-32, https://doi.org/10.1002/joc.1867, 2010.

Coppola, E., Verdecchia, M., Giorgi, F., Colaiuda, V., Tomassetti, B., and Lombardi, A.: Changing hydrological conditions in the Po basin under global warming, Sci. Total Environ., 493, 11831196, https://doi.org/10.1016/j.scitotenv.2014.03.003, 2014.

Coppola, E., Raffaele, F., and Giorgi, F.: Impact of climate change on snow melt driven runoff timing over the Alpine region, Clim. Dynam., https://doi.org/10.1007/s00382-016-3331-0, 2016.

Crosbie, R. S., Binning, P., and Kalma, J. D.: A time series approach to inferring groundwater recharge using the water table fluctuation method, Water Resour. Res., 41, W01008, https://doi.org/10.1029/2004WR003077, 2005.

Dankers, R. and Feyen, L.: Climate change impact on flood hazard in Europe: An assessment based on high-resolution climate simulations, J. Geophys. Res., 113, D19105, https://doi.org/10.1029/2007JD009719, 2008.

da Silva, R. S., Kumar, L., Shabani, F., and Picanço, M. C.: Potential risk levels of invasive Neoleucinodes elegantalis (small tomato borer) in areas optimal for open-field Solanum lycopersicum (tomato) cultivation in the present and under predicted climate change, Pest. Manag. Sci., 73, 616-627, https://doi.org/10.1002/ps.4344, 2017.

Déqué, M.: Frequency of precipitation and temperature extremes over France in an anthropogenic scenario: Model results and statistical correction according to observed values, Global Planet. Change, 57, 16-26, https://doi.org/10.1016/j.gloplacha.2006.11.030, 2007.

Déqué, M., Jones, R. G., Wild, M., Giorgi, F., Christensen, J. H., Hassell, D. C., Vidale, P. L., Rockel, B., Jacob, D., Kjellström, E., de Castro, M., Kucharski, F., and van den Hurk, B.: Global high resolution versus limited area model climate change projections over Europe: quantifying confidence level from PRUDENCE results, Clim. Dynam., 25, 653-670, https://doi.org/10.1007/s00382-005-0052-1, 2005.

Déqué, M., Rowell, D.P., Lüthi, D., Giorgi, F., Christensen, J. H., Rockel, B., Jacob, D., Kjellström, E., de Castro, M., and van den 
Hurk, B.: An intercomparison of regional climate simulations for Europe: assessing uncertainties in model projections, Clim. Change, 81, 53-70, https://doi.org/10.1007/s10584-006-9228-x, 2007.

Dickinson, R. E., Errico, R. M., Giorgi, F., and Bates, G. T.: A regional climate model for the western United States, Clim. Change, 15, 383-442, 1989.

Dickinson, R. E., Henderson-Sellers, A., and Kennedy, P.: Biosphere-atmosphere transfer scheme (BATS) version 1e as coupled to the NCAR community climate model, Tech. Rep., National Center for Atmospheric Research, Boulder, CO, USA, 1993.

Diffenbaugh, N. S. and Giorgi, F.: Climate change hotspots in the CMIP5 global climate model ensemble, Clim. Change, 114, 813822, https://doi.org/10.1007/s10584-012-0570-x, 2012.

Diffenbaugh, N. S., Pal, J. S., Trapp, R. J., and Giorgi, F.: Fine-scale processes regulate the response of extreme events to global climate change, P. Natl. Acad. Sci. USA, 102, 15774-15778, 2005.

Dobler, C., Hagemann, S., Wilby, R. L., and Stötter, J.: Quantifying different sources of uncertainty in hydrological projections in an Alpine watershed, Hydrol. Earth Syst. Sci., 16, 4343-4360, https://doi.org/10.5194/hess-16-4343-2012, 2012.

Dunford, R. W., Smith, A. C., Harrison, P. A., and Hanganu, D.: Ecosystem service provision in a changing Europe: adapting to the impacts of combined climate and socio-economic change, Landscape Ecol., 30, 443-461, https://doi.org/10.1007/s10980014-0148-2, 2015.

EEA: Regional Climate Change and Adaptation, The Alps Facing the Challenge of Changing Water Resources, European Environment Agency, Copenhagen, Denmark, 2009.

Elguindi, N., Bi, X., Giorgi, F., Nagarajan, B., Pal, J., Solmon, F., Rauscher, S., and Zakey, A.: RegCM version 3.1 user's guide, Tech. Rep., ICTP, Trieste, Italy, 2007.

Emanuel, K. A.: A scheme for representing cumulus convection in large-scale models, J. Atmos. Sci., 48, 2313-2329, 1991.

Emanuel, K. A. and Živković-Rothman, M.: Development and evaluation of a convection scheme for use in climate models, J. Atmos. Sci., 56, 1766-1782, 1999.

Faggian, P.: Climate change projections for Mediterranean region with focus over Alpine region and Italy, J. Environ. Sci. Eng. B, 4, 482-500, https://doi.org/10.17265/2162-5263/2015.09.004, 2015.

Feehan, J., Harley, M., and van Minnen, J.: Climate change in Europe. 1. Impact on terrestrial ecosystems and biodiversity. A review, Agron. Sustain. Dev., 29, 409-421, https://doi.org/10.1051/agro:2008066, 2009.

Feng, J., Liu, X., Cassardo, C., and Longhetto, A.: A model of plant transpiration and stomatal regulation under the condition of water stress, J. Desert Res., 17, 59-66, 1997.

Flaschka, I. M., Stockton, C. W., and Boggess, W. R.: Climatic variation and surface water resources in the Great Basin region, Water Resour. Bull., 23, 47-57, 1987.

Francone, C., Cassardo, C., Spanna, F., Alemanno, L., Bertoni, D., Richiardone, R., and Vercellino, I.: Preliminary results on the evaluation of factors influencing evapotranspiration processes in vineyards, Water, 2, 916-937, 2010.

Francone, C., Cassardo, C., Richiardone, R., and Confalonieri, R.: Sensitivity analysis and investigation of the behaviour of the
UTOPIA land-surface process model: A case study for vineyards in northern Italy, Bound.-Lay. Meteorol., 144, 419-430, 2012a.

Francone, C., Katul, G. G., Cassardo, C., and Richiardone, R.: Turbulent transport efficiency and the ejection-sweep motion for momentum and heat on sloping terrain covered with vineyards, Agr. Forest Meteorol., 162-163, 98-107, 2012b.

Frei, C., Schöll, R., Fukutome, S., Schmidli, J., and Vidale, P. L.: Future change of precipitation extremes in Europe: Intercomparison of scenarios from regional climate models, J. Geophys. Res., 111, D06105, https://doi.org/10.1029/2005JD005965, 2006.

Frei, P., Kotlarski, S., Liniger, M. A., and Schär, C.: Future snowfall in the Alps: projections based on the EUROCORDEX regional climate models, The Cryosphere, 12, 1-24, https://doi.org/10.5194/tc-12-1-2018, 2018.

Fronzek, S., Carter, T. R., and Jylhä, K.: Representing two centuries of past and future climate for assessing risks to biodiversity in Europe, Global Ecol. Biogeogr., 21, 19-35, https://doi.org/10.1111/j.1466-8238.2011.00695.x, 2012.

Galli, M., Oh, S., Cassardo, C., and Park, S. K.: The occurrence of cold spells in the Alps related to climate change, Water, 2, 363380, 2010.

Gang, C., Zhang, Y., Wang, Z., Chen, Y., Yang, Y., Li, J., Cheng, J., Qi, J., and Odeh, I.: Modeling the dynamics of distribution, extent, and NPP of global terrestrial ecosystems in response to future climate change, Global Planet. Change, 148, 153-165, 2017.

Gao, X., Pal, J. S., and Giorgi, F.: Projected changes in mean and extreme precipitation over the Mediterranean region from a high resolution double nested RCM simulation, Geophys. Res. Lett., 33, L03706, https://doi.org/10.1029/2005GL024954, 2006.

Gim, H.-J., Park, S. K., Kang, M., Thakuri, B. M., Kim, J., and Ho, C.-H.: An improved parameterization of the allocation of assimilated carbon to plant parts in vegetation dynamics for Noah-MP, J. Adv. Model. Earth Sy., 9, 1776-1794, https://doi.org/10.1002/2016MS000890, 2017.

Giorgi, F.: Simulation of regional climate using a limited area model nested in a general circulation model, J. Climate, 3, 941-963, 1990.

Giorgi, F.: Sensitivity of simulated summertime precipitation over the western United States to different physics parametrization, Mon. Weather Rev., 119, 2870-2888, 1991.

Giorgi, F.: Climate change hot-spots, Geophys. Res. Lett., 33, L08707, https://doi.org/10.1029/2006GL025734, 2006.

Giorgi, F. and Diffenbaugh, N.: Developing regional climate change scenarios for use in assessment of effects on human health and disease, Clim. Res., 36, 141-151, https://doi.org/10.3354/cr00728, 2008.

Giorgi, F. and Lionello, P.: Climate change projections for the Mediterranean region, Global Planet. Change, 63, 90-104, https://doi.org/10.1016/j.gloplacha.2007.09.005, 2008.

Giorgi, F. and Shields, C.: Tests of precipitation parametrizations available in latest version of NCAR regional climate model (RegCM) over continental United States, J. Geophys. Res., 104, 6353-6375, 1999.

Giorgi, F., Bates, G. T., and Nieman, S. J.: The multi-year surface climatology of a regional atmospheric model over the western United States, J. Climate, 6, 75-95, 1993.

Giorgi, F., Hurrell, J. W., Marinucci, M. R., and Beniston, M.: Elevation signal in surface climate change: a model 
study, J. Climate, 10, 288-296, https://doi.org/10.1175/15200442(1997)010<0288:EDOTSC>2.0.CO;2, 1997.

Giorgi, F., Bi, X., and Qian, Y.: Indirect vs. direct effects of anthropogenic sulfate on the climate of East Asia as simulated with a regional coupled climate-chemistry/aerosol model, Clim. Change, 58, 345-376, 2003a.

Giorgi, F., Francisco, R., and Pal, J. S.: Effects of a subgrid-scale topography and land use scheme on the simulation of surface climate and hydrology. Part I: Effects of temperature and water vapour disaggregation, J. Hydrometeorol., 4, 317-333, 2003b.

Giorgi, F., Bi, X., and Pal, J. S.: Mean interannual variability and trends in a regional climate change experiment over Europe. I. Present-day climate (1961-1990), Clim. Dynam., 22, 733-756, 2004a.

Giorgi, F., Bi, X., and Pal, J. S.: Mean interannual variability and trends in a regional climate change experiment over Europe. II: climate change scenarios (2071-2100), Clim. Dynam., 23, 839$858,2004 b$.

Gleick, P. H.: Methods for evaluating the regional hydrologic impacts of global climatic changes, J. Hydrol., 88, 97-116, 1986.

Gleick, P. H.: The development and testing of a water balance model for climate impact assessment: modelling the Sacramento basin, Water Resour. Res., 23, 1049-1061, 1987.

Gobiet, A., Kotlarski, S., Beniston, M., Heinrich, G., Rajczak, J., and Stoffel, M.: 21st century climate change in the European Alps - A review, Sci. Total Environ., 493, 1138-1151, https://doi.org/10.1016/j.scitotenv.2013.07.050, 2014.

Grell, G.: Prognostic evaluation of assumptions used by cumulus parametrizations, Mon. Weather Rev., 121, 764-787, 1993.

Grell, G. A., Dudhia, J., and Stauffer, D.: A description of the fifthgeneration Penn State/NCAR mesoscale model (MM5), Tech. Rep., National Center for Atmospheric Research, Boulder, CO, 1994.

Harrison, P. A., Dunford, R. W., Holman, I. P., and Rounsevell, M. D. A.: Climate change impact modelling needs to include cross-sectoral interactions, Nature Clim. Change, 6, 885-890, https://doi.org/10.1038/nclimate3039, 2016.

Hassan, I., Ghumman, A. R., Ghazaw, Y., Abdel-Maguid, R. H., and Samreen, B.: Climate change impact on precipitation in arid areas of Pakistan, Int. J. Water Resour. Arid Environ., 6, 80-88, 2017.

Heinrich, G., Gobiet, A., and Mendlik, T.: Extended regional climate model projections for Europe until the mid-twentyfirst century: combining ENSEMBLES and CMIP3, Clim. Dynam., 42, 521-535, https://doi.org/10.1007/s00382-013-1840-7, 2014.

Herrera, S., Fita, L., Fernández, J., and Gutiérrez, J. M.: Evaluation of the mean and extreme precipitation regimes from the ENSEMBLES regional climate multimodel simulations over Spain, J. Geophys. Res., 115, D21117, https://doi.org/10.1029/2010JD013936, 2010.

Hong, S., Yu, X., Park, S. K., Choi, Y.-S., and Myoung, B.: Assessing optimal set of implemented physical parameterization schemes in a multi-physics land surface model using genetic algorithm, Geosci. Model Dev., 7, 2517-2529, https://doi.org/10.5194/gmd-7-2517-2014, 2014.

Hong, S., Park, S. K., and Yu, X.: Scheme-based optimization of land surface model using a micro-genetic algorithm: Assessment of its performance and usability for regional applications, Sci. Online Lett. Atmos., 11, 129-133, 2015.
Hoogwijk, M., Faaij, A., Eickhout, B., de Vries, B., and Turkenburg, W.: Potential of biomass energy out to 2100, for four IPCC SRES land-use scenarios, Biomass Bioenerg., 29, 225257, https://doi.org/10.1016/j.biombioe.2005.05.002, 2005.

Hostetler, S. W. and Bartlein, P. J.: Simulation of lake evaporation with application to modelling lake level variations of HarneyMalheur Lake, Oregon, Water Resour. Res., 26, 2603-2612, 1990.

Im, E.-S., Coppola, E., Giorgi, F., and Bi, X.: Local effects of climate change over the Alpine region: A study with a high resolution regional climate model with a surrogate climate change scenario, Geophys. Res. Lett., 37, L05704, https://doi.org/10.1029/2009GL041801, 2010.

IPCC: Climate Change 2007: The Physical Science Basis. Contribution of Working Group I to the Fourth Assessment Report of the Intergovernmental Panel on Climate Change, edited by: Solomon, S., Qin, D., Manning, M., Chen, Z., Marquis, M., Averyt, K. B., Tignor, M., and Miller, H. L., Cambridge University Press, Cambridge, UK, 2007.

IPCC: Climate Change 2013: The Physical Science Basis. Contribution of Working Group I to the Fifth Assessment Report of the Intergovernmental Panel on Climate Change, edited by: Stocker, T. F., Qin, D., Plattner, G.-K., Tignor, M., Allen, S. K., Boschung, J., Nauels, A., Xia, Y., Bex, V., and Midgley, P. M., Cambridge University Press, Cambridge, UK, 2013.

Jacob, D. J. and Winner, D. A.: Effect of climate change on air quality, Atmos. Environ., 43, 51-63, https://doi.org/10.1016/j.atmosenv.2008.09.051, 2009.

Jacob, D., Bärring, L., Christensen, O. B., Christensen, J. H., de Castro, M., Déqué, M., Giorgi, F., Hagemann, S., Hirschi, M., Jones, R., Kjellström, E., Lenderink, G., Rockel, B., Sánchez, E., Schär, C., Seneviratne, S. I., Somot, S., van Ulden, A., and van den Hurk, B.: An inter-comparison of regional climate models for Europe: model performance in present-day climate, Clim. Change, 81, 31-52, https://doi.org/10.1007/s10584-006-9213-4, 2007.

Jacob, D., Göttel, H., Kotlarski, S., and Lorenz, P.: Mögliche Klimaänderungen im Alpenraum, in: Klimawandel in den Alpen: Fakten - Folgen - Anpassung, Bundesministerium für Umwelt, Naturschutz und Reaktorsicherheit, Berlin, Germany, 22-27, 2007.

Jaczewski, A., Brzoska, B., and Wibig, J.: Comparison of temperature indices for three IPCC SRES scenarios based on RegCM simulations for Poland in 2011-2030 period, Meteorol. Z., 24, 99-106, https://doi.org/10.1127/metz/2014/0457, 2015.

Jiang, Z., Song, J., Li, L., Chen, W., Wang, Z., and Wang, J.: Extreme climate events in China: IPCC-AR4 model evaluation and projection, Clim. Change, 110, 385-401, https://doi.org/10.1007/s10584-011-0090-0, 2012.

Jones, C., Lowe, J., Liddicoat, S., and Betts, R.: Committed terrestrial ecosystem changes due to climate change, Nat. Geosci., 2, 484-487, https://doi.org/10.1038/ngeo555, 2009.

Jury, M. W., Prein, A. F., Truhetz, H., and Gobiet, A.: Evaluation of CMIP5 models in the context of dynamical downscaling over Europe, J. Climate, 28, 5575-5582, https://doi.org/10.1175/JCLID-14-00430.1, 2015.

Kiguchi, M., Shen, Y., Kanae, S., and Oki, T.: Re-evaluation of future water stress due to socio-economic and climate fac- 
tors under a warming climate, Hydrolog. Sci. J., 60, 14-29, https://doi.org/10.1080/02626667.2014.888067, 2015.

Kim, S. B., Shin, H. J., Park, M., and Kim, S. J.: Assessment of future climate change impacts on snowmelt and stream water quality for a mountainous high-elevation watershed using SWAT, Paddy Water Environ., 13, 557-569, https://doi.org/10.1007/s10333-014-0471-x, 2015.

Klausmeyer, K.: Effects of climate change on the hydrology of upper Alameda Creek, UC Berkeley: Water Resources Center Archives, available at: http://escholarship.org/uc/item/3tz1153d (last access: 15 September 2017), 2005.

Kotlarski, S., Lüthi, D., and Schär, C.: The elevation dependency of $21 \mathrm{st}$ century European climate change: an RCM ensemble perspective, Int. J. Climatol., 35, 3902-3920, https://doi.org/10.1002/joc.4254, 2015.

Krüger, L. F., da Rocha, R. P., Reboita, M. S., and Ambrizzi, T.: RegCM3 nested in HadAM3 scenarios A2 and B2: projected changes in extratropical cyclogenesis, temperature and precipitation over the South Atlantic Ocean, Clim. Change, 113, 599-621, https://doi.org/10.1007/s10584-011-0374-4, 2012.

Kyselý, J., Gaál, L., Beranová, R., and Plavcová, E.: Climate change scenarios of precipitation extremes in Central Europe from ENSEMBLES regional climate models, Theor. Appl. Climatol., 104, 529-542, https://doi.org/10.1007/s00704-010-0362-z, 2011.

Lam, V. W. Y., Cheung, W. W. L., and Sumaila, U. R.: Marine capture fisheries in the Arctic: winners or losers under climate change and ocean acidification?, Fish Fish., 17, 335-357. https://doi.org/10.1111/faf.12106, 2016.

Lautenschlager, M., Keuler, K., Wunram, C., Keup-Thiel, E., Schubert, M., Will, A., Rockel, B., and Boehm, U.: Climate simulation with CLM, climate of the 20th century, data stream 3: European region MPI-M/MaD, World Data Center for Climate, 2008.

Lavalle, C., Micale, F., Houston, T. D., Camia, A., Hiederer, R., Lazar, C., Conte, C., Amatulli, G., and Genovese, G.: Climate change in Europe. 3. Impact on agriculture and forestry. A review, Agron. Sustain. Dev., 29, 433-446, https://doi.org/10.1051/agro/2008068, 2009.

Lee, Y. H., Park, S. K., and Chang, D.-E.: Parameter estimation using the genetic algorithm and its impact on quantitative precipitation forecast, Ann. Geophys., 24, 3185-3189, https://doi.org/10.5194/angeo-24-3185-2006, 2006.

Lettenmaier, D. P. and Gan, T. Y.: Hydrologic sensitivities of the Sacramento-San Joaquin River Basin, California, to global warming, Water Resour. Res., 26, 69-86, 1990.

Liu, Y., Stanturf, J., and Goodrick, S.: Trends in global wildfire potential in a changing climate, Forest Ecol. Manag., 259, 685-697, 2010.

Loglisci, N., Qian, M. W., Cassardo, C., Longhetto, A., and Giraud, C.: Energy and water balance at soil-air interface in a Sahelian region, Adv. Atmos. Sci., 18, 897-909, 2001.

Luo, Y., Ficklin, D. L., Liu, X., and Zhang, M.: Assessment of climate change impacts on hydrology and water quality with a watershed modeling approach, Sci. Total Environ., 450-451, 72-82, https://doi.org/10.1016/j.scitotenv.2013.02.004, 2013.

Mamoon, A. A., Joergensen, N. E., Rahman, A., and Qasem, H.: Design rainfall in Qatar: sensitivity to climate change scenarios, Nat. Hazards, 81, 1797-1810, https://doi.org/10.1007/s11069016-2156-9, 2016.
Marengo, J. A., Jones, R., Alves, L. M., and Valverde, M. C.: Future change of temperature and precipitation extremes in South America as derived from the PRECIS regional climate modeling system, Int. J. Climatol., 29, 2241-2255, https://doi.org/10.1002/joc.1863, 2009.

Masson, V., Champeaux, J. L., Chauvin, F., Meriguet, C., and Lacaze, R.: A global database of land surface parameters at $1 \mathrm{~km}$ resolution in meteorological and climate models, J. Climate, 16, 1261-1282, 2003 (data available at: https://opensource. umr-cnrm.fr/projects/ecoclimap/files, last access: 15 September 2017).

Matthews, H. D. and Solomon, S.: Irreversible does not mean unavoidable, Science, 340, 438-439, https://doi.org/10.1126/science.1236372, 2013.

Meng, L. and Quiring, S.: A comparison of soil moisture models using soil climate analysis network observations, J. Hydrometeorol., 9, 641-659, 2008.

Moss, R. H., Edmonds, J. A., Hibbard, K. A., Manning, M. R., Rose, S. K., van Vuuren, D. P., Carter, T. R., Emori, S., Kainuma, M., Kram, T., Meehl, G. A., Mitchell, J. F. B., Nakicenovic, N., Riahi, K., Smith, S. J., Stouffer, R. J., Thomson, A. M., Weyant, J. P., and Wilbanks, T. J.: The next generation of scenarios for climate change research and assessment, Nature, 463, 747-756, https://doi.org/10.1038/nature08823, 2010.

Nadeem, I. and Formayer, H.: Sensitivity studies of high-resolution RegCM3 simulations of precipitation over the European Alps: The effect of lateral boundary conditions and domain size, Theor. Appl. Climatol., 126, 617-630, https://doi.org/10.1007/s00704015-1586-8, 2016.

Nakicenovic, N. and Swart, R.: Special Report on Emissions Scenarios: A Special Report of Working Group III of the Intergovernmental Panel on Climate Change, Cambridge University Press, Cambridge, England, 2001.

Nemec, J. and Schaake, J.: Sensitivity of water resources to climate variations, J. Hydrol. Sci., 27, 327-343, 1982.

Nolan, P., O'Sullivan, J., and McGrath, R.: Impacts of climate change on mid-twenty-first-century rainfall in Ireland: a highresolution regional climate model ensemble approach, Int. J. Climatol., 37, 4347-4363, https://doi.org/10.1002/joc.5091, 2017.

Ogden, N. H., Radojević, M., Wu, X., Duvvuri, V. R., Leighton, P. A., and $\mathrm{Wu}, \mathrm{J}$. : Estimated effects of projected climate change on the basic reproductive number of the Lyme disease vector Ixodes scapularis, Environ. Health Persp., 122, 631-638, https://doi.org/10.1289/ehp.1307799, 2014.

O'Sullivan, J., Sweeney, C., Nolan, P., and Gleeson, E.: A high-resolution, multi-model analysis of Irish temperatures for the mid-21st century, Int. J. Climatol., 36, 1256-1267, https://doi.org/10.1002/joc.4419, 2016.

Paeth, H., Vogt, G., Paxian, A., Hertig, E., Seubert, S., and Jacobeit, J.: Quantifying the evidence of climate change in the light of uncertainty exemplified by the Mediterranean hot spot region, Global Planet. Change, 151, 144-151, 2017.

Pal, J. S., Small, E. E., and Eltahir, E. A. B.: Simulation of regionalscale water and energy budgets: Representation of subgrid cloud and precipitation processes within RegCM, J. Geophys. Res., 105, 29579-29594, 2000.

Pal, J. S. and Eltahir, E. A. B.: Teleconnections of soil moisture and rainfall during the 1993 Midwest summer flood, Geophys. Res. Lett., 29, 1865, https://doi.org/10.1029/2002GL014815, 2002. 
Pal, J. S. and Eltahir, E. A. B.: A feedback mechanism between soil moisture distribution and storm tracks, Q. J. Roy. Meteor. Soc., 129, 2279-2297, 2003.

Pal, J. S., Giorgi, F., and Bi, X.: Consistency of recent European summer precipitation trends and extremes with future regional climate projections, Geophys. Res. Lett., 31, L13202, https://doi.org/10.1029/2004GL019836, 2004.

Park, S. K.: Nonlinearity and predictability of convective rainfall associated with water vapor perturbations in a numericallysimulated storm, J. Geophys. Res., 104, 31575-31588, 1999.

Park, S. and Park, S. K.: Parameterization of the snow-covered surface albedo in the Noah-MP Version 1.0 by implementing vegetation effects, Geosci. Model Dev., 9, 1073-1085, https://doi.org/10.5194/gmd-9-1073-2016, 2016.

Park, S. K., O, S., and Cassardo, C.: Soil temperature response in Korea to a changing climate using a land surface model, Asia-Pac. J. Atmos. Sci., 53, 457-470, https://doi.org/10.1007/s13143-017-0048-x, 2017.

Patz, J. A., Campbell-Lendrum, D., Holloway, T., and Foley, J. A.: Impact of regional climate change on human health, Nature, 438, 310-317, https://doi.org/10.1038/nature04188, 2005.

Perez, J., Menendez, M., Mendez, F. J., and Losada, I. J.: Evaluating the performance of CMIP3 and CMIP5 global climate models over the north-east Atlantic region, Clim. Dynam., 43, 26632680, https://doi.org/10.1007/s00382-014-2078-8, 2014.

Peters, G. P., Andrew, R. M., Boden, T., Canadell, J. G., Ciais, P., Le Quéré, C., Marland, G., Raupach, M. R., and Wilson, C.: The challenge to keep global warming below $2{ }^{\circ} \mathrm{C}$, Nature Clim. Change, 3, 4-6, https://doi.org/10.1038/nclimate1783, 2013.

Prino, S., Spanna, F., and Cassardo, C.: Verification of the stomatal conductance of Nebbiolo grapevine, J. Chongqing Univ., 8, 1724, 2009.

Qian, Y., Giorgi, F., Huang, Y., Chameides, W. L., and Luo, C.: Simulation of anthropogenic sulfur over East Asia with a regional coupled chemistry-climate model, Tellus B, 53, 171-191, 2001.

Rauscher, S. A., Coppola, E., Piani, C., and Giorgi, F.: Resolution effects on regional climate model simulations of seasonal precipitation over Europe, Clim. Dynam., 35, 685-711, https://doi.org/10.1007/s00382-009-0607-7, 2010.

Riahi, K., Rao, S., Krey, V., Cho, C., Chirkov, V., Fischer, G., Kindermann, G., Nakicenovic, N., and Rafaj, P.: RCP 8.5 - A scenario of comparatively high greenhouse gas emissions, Clim. Change, 109, 33-57, https://doi.org/10.1007/s10584-011-0149y, 2011.

Rind, D., Rosenzweig, C., and Goldberg, R.: Modelling the hydrological cycle in assessments of climate change, Nature, 358, 119 123, 1992.

Rogelj, J., Meinshausen, M., and Knutti, R.: Global warming under old and new scenarios using IPCC climate sensitivity range estimates, Nature Clim. Change, 2, 248-253, https://doi.org/10.1038/nclimate1385, 2012.

Rummukainen, M.: Changes in climate and weather extremes in the 21st century, WIREs Clim. Change, 3, 115-129, https://doi.org/10.1002/wcc.160, 2012.

Ruti, P. M., Cassardo, C., Cacciamani, C., Paccagnella, T., Longhetto, A., and Bargagli, A.: Intercomparison between BATS and LSPM surface schemes, using point micrometeorological data set, Contrib. Atmos. Phys., 70, 201-220, 1997.
Shaltout, M. and Omstedt, A.: Recent precipitation trends and future scenarios over the Mediterranean Sea, Geofizika, 31, 127150, https://doi.org/10.15233/gfz.2014.31.7, 2014.

Shen, Y., Oki, T., Utsumi, N., Kanae, S., and Hanasaki, N.: Projection of future world water resources under SRES scenarios: water withdrawal, Hydrolog. Sci. J., 53, 11-33, https://doi.org/10.1623/hysj.53.1.11, 2008.

Shen, Y., Oki, T., Kanae, S., Hanasaki, N., Utsumi, N., and Kiguchi, M.: Projection of future world water resources under SRES scenarios: an integrated assessment, Hydrolog. Sci. J., 59, 17751793, https://doi.org/10.1080/02626667.2013.862338, 2014.

Skalák, P., Déqué, M., Belda, M., Farda, A., Halenka, T., Csima, G., Bartholy, J., Caian, M., and Spiridonov, V.: CECILIA regional climate simulations for the present climate: validation and inter-comparison, Clim. Res., 60, 1-12, https://doi.org/10.3354/cr01207, 2014.

Smiatek, G., Kunstmann, H., Knoche, R., and Marx, A.: Precipitation and temperature statistics in high-resolution regional climate models: Evaluation for the European Alps, J. Geophys. Res., 114, D19107, https://doi.org/10.1029/2008JD011353, 2009.

Solomon, F., Giorgi, F., and Liousse, C.: Aerosol modelling for regional climate studies: Application to anthropogenic particles and evaluation over a European/African domain, Tellus B, 58, 51-72, 2006.

Stevanović, M., Popp, A., Lotze-Campen, H., Dietrich, J. P., Müller, C., Bonsch, M., Schmitz, C., Bodirsky, B. L., Humpenöder, F., and Weindl, I.: The impact of high-end climate change on agricultural welfare, Sci. Adv., 2, e1501452, https://doi.org/10.1126/sciadv.1501452, 2016.

Tainio, M., Juda-Rezler, K., Reizer, M., Warchalowski, A., Trapp, W., and Skotak, K.: Future climate and adverse health effects caused by fine particulate matter air pollution: case study for Poland, Reg. Environ. Change, 13, 705-715, https://doi.org/10.1007/s10113-012-0366-6, 2013.

Torma, C., Coppola, E., Giorgi, F., Bartholy, J., and Pongrácz, R.: Validation of a high-resolution version of the regional climate model RegCM3 over the Carpathian basin, J. Hydrometeorol., 12, 84-100, https://doi.org/10.1175/2010JHM1234.1, 2011.

Torma, C., Giorgi, F., and Coppola, E.: Added value of regional climate modeling over areas characterized by complex terrain Precipitation over the Alps, J. Geophys. Res.-Atmos., 120, 39573972, https://doi.org/10.1002/2014JD022781, 2015.

Tukimat, N. N. A. and Alias, N. A.: Assessment the potential of SRES scenario for Kuala Sala, Malaysia, IOSR J. Mech. Civil Eng., 13, 6-12, 2016.

van Vliet, M. T. H., Yearsley, J. R., Ludwig, F., Vögele, S., Lettenmaier, D. P., and Kabat, P.: Vulnerability of US and European electricity supply to climate change, Nature Clim. Change, 2, 676-681, https://doi.org/10.1038/nclimate1546, 2012.

Vautard, R., Gobiet, A., Sobolowski, S., Kjellström, E., Stegehuis, A., Watkiss, P., Mendlik, T., Landgren, O., Nikulin, G., Teichmann, C., and Jacob, D.: The European climate under a $2{ }^{\circ} \mathrm{C}$ global warming, Environ. Res. Lett., 9, 034006, https://doi.org/10.1088/1748-9326/9/3/034006, 2014.

Walz, A., Braendle, J. M., Lang, D. J., Brand, F., Briner, S., Elkin, C., Hirschi, C., Huber, R., Lischke, H., and Schmatz, D. R.: Experience from downscaling IPCC-SRES scenarios to specific national-level focus scenarios for ecosystem service 
management, Technol. Forecasting Social Change, 86, 21-32, https://doi.org/10.1016/j.techfore.2013.08.014, 2014.

Ward, J. D., Werner, A. D., Nel, W. P., and Beecham, S.: The influence of constrained fossil fuel emissions scenarios on climate and water resource projections, Hydrol. Earth Syst. Sci., 15, 18791893, https://doi.org/10.5194/hess-15-1879-2011, 2011.

Westerling, A. L., Bryant, B. P., Preisler, H. K., Holmes, T. P., Hidalgo, H. G., Das, T., and Shrestha, S. R.: Climate change and growth scenarios for California wildfire, Clim. Change, 109, 445-463, https://doi.org/10.1007/s10584-011-0329-9, 2011.

White, M., Diffenbaugh, N., Jones, G., Pal, J. S., and Giorgi, F.: Increased heat stress in the 21 st century reduces and shifts premium wine production in the United States, P. Natl. Acad. Sci. USA, 103, 11217-11222, 2006.

Wilby, R. L. and Wigley, T. M. L.: Downscaling general circulation model output: a review of methods and limitations, Prog. Phys. Geog., 21, 530-548, https://doi.org/10.1177/030913339702100403, 1997.

Wilby, R. L., Whitehead, P. G., Wade, A. J., Butterfield, D., Davis, R. J., and Watts, G.: Integrated modelling of climate change impacts on water resources and quality in a lowland catchment: River Kennet, UK, J. Hydrol., 330, 204-220, https://doi.org/10.1016/j.jhydrol.2006.04.033, 2006.

$\mathrm{Xu}, \mathrm{C} .-$ Y. and Singh, V. P.: A review on monthly water balance models for water resources investigation and climatic impact assessment, Water Resour. Manag., 12, 31-50, 1998.

Yu, X., Park, S. K., Lee, Y. H., and Choi, Y.-S.: Quantitative precipitation forecast of a tropical cyclone through optimal parameter estimation in a convective parameterization, Sci. Online Lett. Atmos., 9, 36-39, 2013.
Zanis, P., Ntogras, C., Zakey, A., Pytharoulis, I., and Karacostas, T.: Regional climate feedback of anthropogenic aerosols over Europe using RegCM3, Clim. Res., 52, 267-278, https://doi.org/10.3354/cr01070, 2012.

Zhang, Y., Cassardo, C., Ye, C., and Galli, M.: A landfall typhoon simulation in a coupled land surface process model with WRF, in: Preprints, Conf. on MCSs and High-Impact Weather/Climate in East Asia (ICMCS-VII), 11-13 November 2009, Seoul, Korea, 114-121, 2009.

Zhang, Y., Cassardo, C., Ye, C., Galli, M., and Vela, N.: The role of the land surface processes in the rainfall generated by a landfall typhoon: A simulation of the Typhoon Sepat (2007), Asia-Pac. J. Atmos. Sci., 47, 63-77, 2011.

Zheng, X., Wang, C., Cai, W., Kummu, M., and Varis, O.: The vulnerability of thermoelectric power generation to water scarcity in China: Current status and future scenarios for power planning and climate change, Appl. Energ., 171, 444-455, https://doi.org/10.1016/j.apenergy.2016.03.040, 2016.

Zubizarreta-Gerendiain, A., Pukkala, T., and Peltola, H.: Effects of wood harvesting and utilisation policies on the carbon balance of forestry under changing climate: a Finnish case study, Forest Policy Economics, 62, 168-176, https://doi.org/10.1016/j.forpol.2015.08.007, 2016. 